Classification

Physics Abstracts

61.16.d - 61.72.Ff $-73.40 . \mathrm{Vz}$

\title{
Mixed Layers in Copper Based Superconducting Materials
}

\author{
Maryvonne Hervieu $\left({ }^{1}\right)$, Gustaaf Van Tendeloo $\left({ }^{2}\right)$, Claude Michel $\left({ }^{1}\right)$, Denis Pelloquin $\left({ }^{1}\right)$ \\ and Bernard Raveau $\left({ }^{1}\right)$
}

$\left({ }^{1}\right)$ Laboratoire de Cristallographie et Sciences des Matériaux, ISMRA/Université de Caen, Boulevard du Maréchal Juin, 14050 Caen Cedex, France

$\left({ }^{2}\right)$ EMAT, University of Antwerp (RUCA), Groenenborgerlaan 171, 2020, Antwerp, Belgium

(Received February 19, accepted March 27, 1996)

\begin{abstract}
Recently discovered series of high Tc superconductors, characterized by the existence of two types of cations within the same layer, are presented. The first family concerns the mercury based cuprates, $\mathrm{Hg}_{1-x} \mathrm{M}_{x} \mathrm{~A}_{2} \mathrm{Ca}_{m-1} \mathrm{Cu}_{m} \mathrm{O}_{2 m+2+\delta}$, with $\mathrm{A}=\mathrm{Ba}$ and/or $\mathrm{Sr}$, which exhibit structures closely related to that of the thallium cuprates $\mathrm{TlBa}_{2} \mathrm{Ca}_{m-1} \mathrm{Cu}_{m} \mathrm{O}_{2 m+3}$. They differ from the thallium cuprates by a high oxygen deficiency at the level of the mercury layer. It is shown that cations such as $\mathrm{M}=\mathrm{Cu}, \mathrm{Pb}, \mathrm{Tl}, \mathrm{Bi}, \mathrm{Ce}, \mathrm{Pr}, \mathrm{Cr}, \mathrm{V}, \mathrm{Mo}, \mathrm{W}, \mathrm{Ti}, \mathrm{Sr}, \mathrm{Ca}, \ldots$ can partially substitute for mercury ions, stabilizing the structures. The cationic composition of the layer depends indeed on the nature of the $\mathrm{M}$ cation but also on that of the alkaline earth $\mathrm{A}$. For given $\mathrm{A}$ and $\mathrm{M}$ cations, the $x$ value remains unchanged even when the number of copper layers varies. $\mathrm{M}$ and $\mathrm{Hg}$ cations are either statistically distributed over the same site or ordered. Different types of ordering have been detected. Another way of generating mixed layers is to shear periodically the structure, leading to the formation of the so called "collapsed phase". In the collapsed bismuth cuprates, bismuth and copper segments, a few octahedra long, alternate in strongly waving layers. In the collapsed oxycarbonates, carbonate groups and $\mathrm{M}$ cations are ordered within the intermediate layer so that they can be simply described from a partial and ordered substitution of carbon for $\mathrm{Hg}, \mathrm{Tl}, \mathrm{Bi}$ and other $\mathrm{M}$ cations building the intermediate layer. The oxycarbonitrates $\left(\mathrm{Y}_{1-x} \mathrm{Ca}_{x}\right)_{n} \mathrm{Ba}_{2 n} \mathrm{Cu}_{3 n-1}(\mathrm{C}, \mathrm{N}) \mathrm{O}_{3} \mathrm{O}_{7 n-3}$ can also be described as an ordered substitution of carbon for copper in the 123 matrix. The different families of superconducting materials which are generated by such mechanisms are described as well as the way the different species are distributed within the mixed layers. Their influence on the physical properties are discussed.
\end{abstract}

\section{Introduction}

An efficient way to modify the chemical and physical properties of metal oxides is to control their stoichiometry, using especially ionic substitutions. Charge, ionic radius and electronic configuration of the ions, but also the framework they adopt, are therefore key factors. The perovskite structure $\mathrm{AMO}_{3-x}$ is one of the most fascinating frameworks. Its great flexibility and 


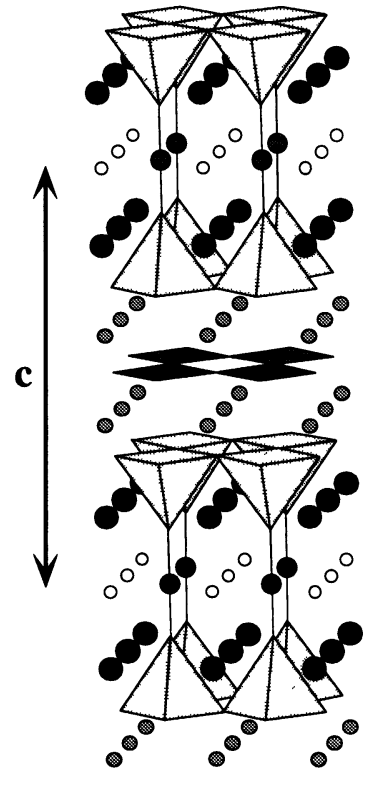

a)

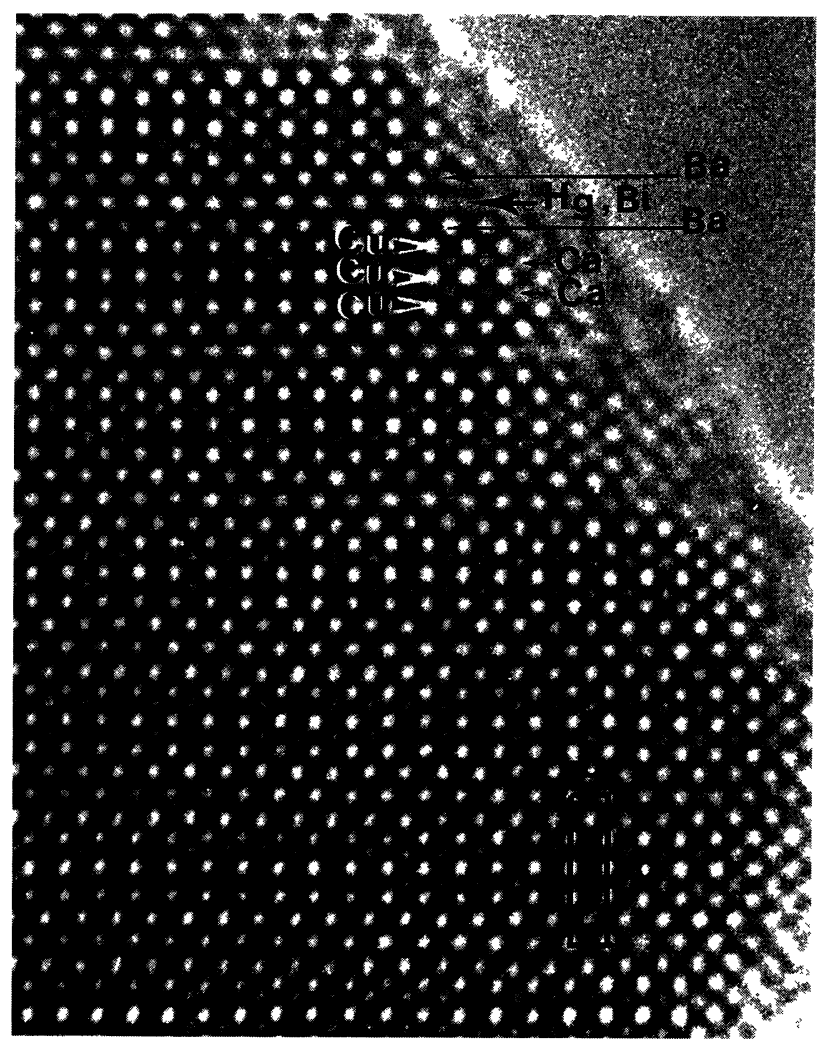

b)

Fig. 1. - $\mathrm{Hg}_{0.8} \mathrm{Bi}_{0.2} \mathrm{Ba}_{2} \mathrm{Ca}_{2} \mathrm{Cu}_{3} \mathrm{O}_{8}$ : a) idealized model of the 1223-type structure, b) [001] HREM image. The cation positions are imaged as bright dots; they are indicated for every layer of the 1223-type structure. The layer stacking along $\mathbf{c}$ is very regular.

adaptability to other structural families allow numerous substitutions to be expected without any drastic structural change. A large range of chemical and physical properties which strongly depend on the stoichiometry make them very attractive. High temperature superconductivity is one of them and the structure of the layered cuprates is a perfect model for illustrating the way several species can be distributed within the same layer.

The parent structures of the copper based high Tc superconductors result from the ordered intergrowth of $n$ rock salt-type and $m$ oxygen deficient perovskite-type layers. This can be simply expressed through the general formula $[\mathrm{AO}]_{n}\left[\mathrm{~A}^{\prime} \mathrm{CuO}_{3-x}\right]_{m}$ (see Ref. [1] for review). The idealized structure of the $n=2, m=3$ member is shown in Figure 1. The bidimensional character of the structure and the mixed valence of copper are two essential parameters for superconductivity. Therefore, two types of layers are of importance: the copper layers, but also the intermediate [AO] layers of the rock salt "slice" which are supposed to play the role of hole reservoir. New copper based superconductors and related structures have been recently discovered, where mixed layers are formed, due to the occupancy of the metal sites by at least two types of cations in an ordered or random manner. These mixed layers result from chemical mechanisms by stabilizing substitution solid solutions but also from more complex structural mechanisms such as 
crystallographic shearings. Three families are described in more detail here: the mercury based cuprates $\left[\mathrm{Hg}_{1-x} \mathrm{M}_{x}\right] \mathrm{A}_{2} \mathrm{Ca}_{m-1} \mathrm{Cu}_{m} \mathrm{O}_{2 m+2+\delta}$ with $\mathrm{A}=\mathrm{Ba}$ or $\mathrm{Sr}$, the collapsed bismuth cuprates and the collapsed superconducting oxycarbonates where carbonate groups are inserted in the framework.

\section{Stabilisation of Lead and Mercury Based Cuprates}

The first evidence of the stabilization of copper superconductors by mixing two types of cations within the intermediate layer of the rock salt-type slice was observed in the lead 1212's material. The exploration of the lead based oxide systems according to the general formula $\left[\mathrm{Pb}_{1-x} \mathrm{M}_{x}\right] \mathrm{Sr}_{2}$ $\mathrm{Ca}_{0.5} \mathrm{Y}_{0.5} \mathrm{Cu}_{2} \mathrm{O}_{7}$ allowed to isolate nine superconductors with Tc's up to $95 \mathrm{~K}$; for $x=0.5, \mathrm{M}=\mathrm{Ca}$, $\mathrm{Sr}, \mathrm{Cd}, \mathrm{Mg}, \mathrm{Ni}, \mathrm{Zn}, \mathrm{Cu}, \mathrm{In}, \mathrm{Ga}$ [2-7] and for $x=0.3, \mathrm{M}=\mathrm{Sc}$ and $\mathrm{Fe}$ [8]. These cuprates exhibit a rock salt-type slice built from one mixed $\left[\mathrm{Pb}_{1-x} \mathrm{M}_{x} \mathrm{O}\right]$ layer surrounded by two [SrO] layers. Electron diffraction (ED) and high resolution electron microscopy (HREM) studies could not detect any ordering between $\mathrm{Pb}$ and $\mathrm{M}$ in the mixed layer, whatever the nature of $\mathrm{M}$. The critical temperatures range between 0 and $95 \mathrm{~K}$, depending on the nature, especially the ionic radius, of the cation. Moreover, Tc exhibits a maximum versus the oxygen partial pressure indicating that the oxygen content is another important factor. It appears, in fact, that the nature of the cation $\mathrm{M}$ influences the redox equilibria $\mathrm{Pb}^{\mathrm{II}} / \mathrm{Pb}^{\mathrm{IV}}$ and $\mathrm{Cu}^{\mathrm{II}} / \mathrm{Cu}^{\mathrm{III}}$. The formation of mixed rock salt-type layers appears to be essential for the stabilization of the lead based cuprates, since no undoped lead material has been isolated until now.

The discovery of the 1201-type $94 \mathrm{~K}$ superconductor, $\mathrm{HgBa}_{2} \mathrm{CuO}_{4+\delta}$ [9], showed that mercury is able to lead to the formation of new cuprates, isotypic to the thallium series. Few months later, the 1212, 1223 and 1234 members were stabilized, corresponding to the general formula $\mathrm{HgBa}_{2} \mathrm{Ca}_{m-1} \mathrm{Cu}_{m} \mathrm{O}_{2 m+2+\delta}$ with $m=1,2,3$ and 4 respectively [10-13]. Owing to its preference for a twofold coordination, mercury is susceptible to ensure the junction between either octahedral perovskite layers (in 1201) or pyramidal copper layers (in 1212 and higher members), forming linear $\mathrm{Hg}^{\mathrm{II}} \mathrm{O}_{2}$ groups. As a result, the intermediate mercury layer is lacunar, so that it can accommodate the oxygen content necessary to create the mixed valence $\mathrm{Cu}^{\mathrm{II}} / \mathrm{Cu}^{\mathrm{III}}$. The problem of these new materials is that they need drastic conditions of synthesis (either very high pressures or moisture and $\mathrm{CO}_{2}$ free atmospheres) so that they can hardly be isolated. Moreover, no pure strontium equivalent series, $\mathrm{HgSr}_{2} \mathrm{Ca}_{m-1} \mathrm{Cu}_{m} \mathrm{O}_{2 m+2+\delta}$, could be synthesised up to now. The lacunar character of the mercury layers can originate this metastability. A partial substitution of mercury by a second $\mathrm{M}$ cation, which would exhibit a higher oxydation state, is a way to incorporate additional oxygen atoms within the intermediate layer.

In the strontium based cuprates, $\mathrm{Hg}_{1-x} \mathrm{M}_{x} \mathrm{Sr}_{2} \mathrm{Ca}_{m-1} \mathrm{Cu}_{m} \mathrm{O}_{2 m+2+\delta}((\mathrm{Hg}, \mathrm{M}) \mathrm{SC})$, mixed layers have been conceived with $\mathrm{M}=\mathrm{Cu}, \mathrm{Sr}, \mathrm{Bi}, \mathrm{Tl}, \mathrm{Pb}, \mathrm{Pr}, \mathrm{Cr}, \mathrm{Mo}, \mathrm{Ce}, \mathrm{Re}$; they are either of 1201-type [14-17] or of 1212-type [18-24]. In the barium based cuprates, $\mathrm{Hg}_{1-x} \mathrm{M}_{x} \mathrm{Ba}_{2} \mathrm{Ca}_{m-1} \mathrm{Cu}_{m} \mathrm{O}_{2 m+2+\delta}$ ((Hg,M)BC), M can be $\mathrm{Ca}, \mathrm{Bi}, \mathrm{Pb}, \mathrm{V}, \mathrm{Mo}, \mathrm{W}, \mathrm{Ti}, \mathrm{Cr}, \mathrm{Al}, \mathrm{Ga}, \mathrm{Ge}$ [25-30] and the 1201, 1212 and 1223's members have been isolated. They are listed in tables I and II. The M cations are so different (ionic radius, electronic configuration..) that one can rise the question: how these cations are distributed within the layers?

1.1 LAYERS STACKING. - The stacking sequences of the rock salt and perovskite layers along the $\mathrm{c}$ axis, for the different the 1201, 1212 and 1223-types, are generally highly regular. This is illustrated by a single example displayed in Figure $1 \mathrm{~b}$, the 1223 cuprate $\mathrm{Hg}_{0.8} \mathrm{Bi}_{0.2} \mathrm{Ba}_{2} \mathrm{Ca}_{2} \mathrm{Cu}_{3} \mathrm{O}_{8+\delta}$, where the positions of the cations are imaged as white dots so that the sequence of the layers along c can be easily identified (marked in the right part of the micrograph). 
Table I. - Characteristics of the "1201"and "1212" (Hg, M)SC cuprates Cell parameters and $T_{\mathrm{c}}$ (onset) (N.S. = non superconducting material).

\begin{tabular}{|c|c|c|c|c|c|}
\hline \multirow[t]{2}{*}{ nominal composition } & \multirow[t]{2}{*}{ (EDS) } & \multicolumn{3}{|c|}{ cell parameters } & \multirow[t]{2}{*}{$\mathbf{T c}(\mathbf{K})$} \\
\hline & & $\mathbf{a}(\AA)$ & $\mathbf{b}(\AA)$ & $\mathbf{c}(\mathbf{A})$ & \\
\hline \multicolumn{6}{|l|}{ "1201"-structure } \\
\hline $\mathrm{Hg}_{0.5} \mathrm{Bi}_{0.5} \mathrm{Sr}_{2-\mathrm{x}} \mathrm{La}_{\mathrm{X}} \mathrm{CuO}_{4+\delta}$ & $0-0.75$ & $3.765-3.778$ & & $8.94-8.84$ & 27 \\
\hline $\mathrm{Hg}_{0.3} \mathrm{~Pb}_{0.7} \mathrm{Sr}_{2-\mathrm{x}} \mathrm{La}_{\mathrm{X}} \mathrm{CuO}_{4+\delta}$ & $0-0.65$ & $3.749-3.768$ & & $8.87-8.99$ & 40 \\
\hline $\mathrm{Hg}_{0.4} \mathrm{Pr}_{0.6} \mathrm{Sr}_{2-\mathrm{x}} \mathrm{Pr}_{\mathrm{X}} \mathrm{CuO}_{4+\delta}$ & $0-0.1$ & 7.606 & 3.683 & 8.88 & N.S. \\
\hline$\left(\mathrm{Hg}_{0.4} \mathrm{Ce}_{0.5} \mathrm{Sr}_{0.1}\right) \mathrm{Sr}_{2-\mathrm{x}} \mathrm{La}_{x} \mathrm{CuO}_{4+\delta}$ & $0.4-0.8$ & $3.733-3.738$ & 7.573 & 17.947- & N.S. \\
\hline$\left(\mathrm{Hg}_{1-\mathrm{x}} \mathrm{Cr}_{\mathrm{X}}\right) \mathrm{Sr}_{2} \mathrm{CuO}_{4+\delta}$ & $0.3-0.4$ & $3.840-3.854$ & & $8.705-8.639$ & 58 \\
\hline $\mathrm{Hg}_{0.5} \mathrm{Mo}_{0.5} \mathrm{Sr}_{2} \mathrm{CuO}_{4+\delta}$ & & 3.787 & & 8.844 & N.S. \\
\hline \multicolumn{6}{|l|}{ "1212"-structure } \\
\hline $\mathrm{Hg}_{0.3} \mathrm{~Pb}_{0.7} \mathrm{Sr}_{2} \mathrm{Ca}_{0.7} \mathrm{Nd}_{0.3} \mathrm{Cu}_{2} \mathrm{O}_{7}$ & & 3.81 & & 12.13 & 100 \\
\hline $\mathrm{Hg}_{0.5} \mathrm{Bi}_{0.5} \mathrm{Sr}_{2} \mathrm{Ca}_{1-\mathrm{x}} \mathrm{Nd}_{\mathrm{x}} \mathrm{Cu}_{2} \mathrm{O}_{6+\delta}$ & $0.35-1$ & $3.809-3.854$ & & $12.06-11.99$ & 94 \\
\hline $\mathrm{Hg}_{0.5} \mathrm{Bi}_{0.5} \mathrm{Sr}_{2} \mathrm{Ca}_{0.65} \mathrm{Y}_{0.35} \mathrm{Cu}_{2} \mathrm{O}_{6+\delta}$ & & 3.795 & & 12.036 & 92 \\
\hline $\mathrm{Hg}_{0.5} \mathrm{Bi}_{0.5} \mathrm{Sr}_{2} \mathrm{Ca}_{0.65} \operatorname{Pr}_{0.35} \mathrm{Cu}_{2} \mathrm{O}_{6}+\delta$ & & 3.805 & & 12.054 & 95 \\
\hline $\mathrm{Hg}_{0.4} \operatorname{Pr}_{0.6} \mathrm{Sr}_{2} \mathrm{Sr}_{1-\mathrm{x}} \mathrm{Pr}_{\mathrm{x}} \mathrm{Cu}_{2} \mathrm{O}_{6+\delta}$ & $0.2-0.7$ & $3.838-3.864$ & $3.819-3.838$ & $12.22-12.26$ & 85 \\
\hline $\mathrm{Hg}_{0.4} \mathrm{Pr}_{0.6} \mathrm{Sr}_{2} \mathrm{Ca}_{1-\mathrm{x}} \mathrm{Pr}_{\mathrm{x}} \mathrm{Cu}_{2} \mathrm{O}_{6+\delta}$ & $0.2-0.7$ & $3.833-3.846$ & $3.795-3.802$ & 12.15 & 85 \\
\hline $\mathrm{Hg}_{0.4} \mathrm{Ce}_{0.5} \mathrm{Sr}_{2.5} \mathrm{Ca}_{0.5} \mathrm{Cu}_{2.1} \mathrm{O}_{7}$ & & 7.626 & 3.813 & 12.19 & 51 \\
\hline $\mathrm{Hg}_{0.7} \mathrm{Cr}_{0.3} \mathrm{Sr}_{2} \mathrm{Ca}_{0.7} \mathrm{Y}_{0.3} \mathrm{Cu}_{2} \mathrm{O}_{6+\delta}$ & & 3.853 & & 11.819 & N.S. \\
\hline $\mathrm{Hg}_{0.7} \mathrm{Mo}_{0.3} \mathrm{Sr}_{2} \mathrm{Ca}_{0.7} \mathrm{Y}_{0.3} \mathrm{Cu}_{2} \mathrm{O}_{6+\delta}$ & & 3.82 & & 11.94 & 95 \\
\hline $\mathrm{Hg}_{0.75} \mathrm{Nb}_{0.25} \mathrm{Sr}_{2} \mathrm{Nd}_{1-\mathrm{x}} \mathrm{Ca}_{\mathrm{x}} \mathrm{Cu}_{2} \mathrm{O}_{6+\delta}$ & $0-0.4$ & $3.852-3.839$ & & $11.96-11.99$ & 80 \\
\hline
\end{tabular}

1.2 Cationic Distribution. - Electron microscopy and EDS analyses clearly illustrate that the content $x$ of the foreign cation follows two general rules. First, for a given cation $M$ and a given alkaline earth $\mathrm{A}, x$ value remains unchanged for the different members of a series; for instance, $x$ is $0.5\left(\mathrm{Hg}_{0.5} \mathrm{Bi}_{0.5}\right)$ for the 1201 and 1212 strontium cuprates and $0.2\left(\mathrm{Hg}_{0.8} \mathrm{Bi}_{0.2}\right)$ for the 1201, 1212 and 1223 barium cuprates. Second, $x$ is lower in the barium compounds than in the strontium compounds. This is consistent with the existence of the "pure" barium cuprates and with the non existence of the "pure" strontium compounds. Such a behaviour emphasizes the role of the foreign cation in the stabilization of the strontium mercury based cuprates. Another problem is the distribution of $\mathrm{Hg}$ and $\mathrm{M}$ within the intermediate layer. In the strontium based compounds, we observe two types of behavior depending on the nature of the cation. 
Table II. - Characteristics of the "1201", "1212" and "1223-(Hg, M)BC cuprates Cell parameters and $T_{\mathrm{c}}$ (onset) (N.S. = non superconducting material).

\begin{tabular}{|c|c|c|c|c|}
\hline \multirow[t]{2}{*}{ Nominal composition } & \multirow{2}{*}{$\begin{array}{c}\text { EDS analysis } \\
\text { (cations) }\end{array}$} & \multicolumn{2}{|c|}{ Cell parameters } & \multirow{2}{*}{ Tc (onset) } \\
\hline & & $\mathbf{a}(\AA)$ & $\mathbf{c}(\AA)$ & \\
\hline \multicolumn{5}{|l|}{ "1201"-structure } \\
\hline $\mathrm{Hg}_{0.9} \mathrm{Ba}_{2} \mathrm{CuO}_{4+\delta}$ & ----- & 3.8830 & 9.536 & $91 \mathrm{~K}$ \\
\hline $\mathrm{Hg}_{0.8} \mathrm{~V}_{0.2} \mathrm{Ba}_{2} \mathrm{CuO}_{4.3}$ & $\mathrm{Hg}_{0.8} \mathrm{~V}_{0.2} \mathrm{Ba}_{2} \mathrm{Cu}$ & 3.8863 & 9.338 & $96 \mathrm{~K}$ \\
\hline $\mathrm{Hg}_{0.8} \mathrm{Mo}_{0.2} \mathrm{Ba}_{2} \mathrm{CuO}_{4.4}$ & $\mathrm{Hg}_{0.75} \mathrm{Mo}_{0.25} \mathrm{Ba}_{2} \mathrm{Cu}$ & 3.8819 & 9.378 & $74 \mathrm{~K}$ \\
\hline $\mathrm{Hg}_{0.9} \mathrm{Mo}_{0.1} \mathrm{Ba}_{2} \mathrm{CuO}_{4.2}$ & $\mathrm{Hg}_{0.9} \mathrm{Mo}_{0.1} \mathrm{Ba}_{2} \mathrm{Cu}$ & 3.8748 & 9.435 & $75 \mathrm{~K}$ \\
\hline $\mathrm{Hg}_{0.8} \mathrm{~W}_{0.2} \mathrm{Ba}_{2} \mathrm{CuO}_{4.4}$ & $\mathrm{Hg}_{0.75} \mathrm{~W}_{0.25} \mathrm{Ba}_{2} \mathrm{Cu}$ & 3.8713 & 9.416 & $45 \mathrm{~K}$ \\
\hline $\mathrm{Hg}_{0.9} \mathrm{~W}_{0.1} \mathrm{Ba}_{2} \mathrm{CuO}_{4.2}$ & $\mathrm{Hg}_{0.9} \mathrm{~W}_{0.1} \mathrm{Ba}_{2} \mathrm{Cu}$ & 3.8746 & 9.450 & $89 \mathrm{~K}$ \\
\hline $\mathrm{Hg}_{0.8} \mathrm{Cr}_{0.2} \mathrm{Ba}_{2} \mathrm{CuO}_{4.1}$ & $\mathrm{Hg}_{0.6} \mathrm{Cr}_{0.4} \mathrm{Ba}_{2} \mathrm{Cu}$ & 3.9261 & 9.306 & N.S. \\
\hline $\mathrm{Hg}_{0.8} \mathrm{Mn}_{0.2} \mathrm{Ba}_{2} \mathrm{CuO}_{4.2}$ & $\mathrm{Hg}_{0.8} \mathrm{Mn}_{0.2} \mathrm{Ba}_{2} \mathrm{Cu}$ & 3.890 & 9.343 & $94 \mathrm{~K}$ \\
\hline $\mathrm{Hg}_{0.8} \mathrm{Nb}_{0.2} \mathrm{Ba}_{2} \mathrm{CuO}_{4.3}$ & $\mathrm{Hg}_{0.75} \mathrm{Nb}_{0.25} \mathrm{Ba}_{2} \mathrm{Cu}$ & 3.885 & 9.461 & $82 \mathrm{~K}$ \\
\hline $\mathrm{Hg}_{0.8} \mathrm{Bi}_{0.2} \mathrm{Ba}_{2} \mathrm{CuO}_{4.2}$ & $\mathrm{Hg}_{0.75} \mathrm{Bi}_{0.25} \mathrm{Ba}_{2} \mathrm{Cu}$ & 3.876 & 9.475 & $84 \mathrm{~K}$ \\
\hline \multicolumn{5}{|l|}{ "1212"-structure } \\
\hline $\mathrm{HgBa}_{2} \mathrm{CaCu}_{2} \mathrm{O}_{6+\delta}$ & $-\cdots$ & 3.8624 & 12.704 & $117 \mathrm{~K}$ \\
\hline $\mathrm{Hg}_{0.8} \mathrm{~V}_{0.2} \mathrm{Ba}_{2} \mathrm{CaCu}_{2} \mathrm{O}_{6.3}$ & $\mathrm{Hg}_{0.8} \mathrm{~V}_{0.2} \mathrm{Ba}_{2} \mathrm{CaCu}_{2}$ & 3.8692 & 12.500 & $119 \mathrm{~K}$ \\
\hline $\mathrm{Hg}_{0.8} \mathrm{Mo}_{0.2} \mathrm{Ba}_{2} \mathrm{CaCu}_{2} \mathrm{O}_{6.4}$ & $\mathrm{Hg}_{0.75} \mathrm{Mo}_{0.25} \mathrm{Ba}_{2} \mathrm{CaCu}_{2}$ & 3.8602 & 12.576 & $127 \mathrm{~K}$ \\
\hline $\mathrm{Hg}_{0.8} \mathrm{~W}_{0.2} \mathrm{Ba}_{2} \mathrm{CaCu}_{2} \mathrm{O}_{6.4}$ & $\mathrm{Hg}_{0.75} \mathrm{~W}_{0.25} \mathrm{Ba}_{2} \mathrm{CaCu}_{2}$ & 3.8607 & 12.661 & $118 \mathrm{~K}$ \\
\hline $\mathrm{Hg}_{0.9} \mathrm{~W}_{0.1} \mathrm{Ba}_{2} \mathrm{CaCu}_{2} \mathrm{O}_{6.2}$ & $\mathrm{Hg}_{0.9} \mathrm{~W}_{0.1} \mathrm{Ba}_{2} \mathrm{CaCu}_{2}$ & 3.8635 & 12.685 & $118 \mathrm{~K}$ \\
\hline $\mathrm{Hg}_{0.8} \mathrm{Ti}_{0.2} \mathrm{Ba}_{2} \mathrm{CaCu}_{2} \mathrm{O}_{6.2}$ & $\mathrm{Hg}_{0.7} \mathrm{Ti}_{0.3} \mathrm{Ba}_{2} \mathrm{CaCu}_{2}$ & 3.8568 & 12.581 & $127 \mathrm{~K}$ \\
\hline $\mathrm{Hg}_{0.8} \mathrm{Cr}_{0.2} \mathrm{Ba}_{2} \mathrm{CaCu}_{2} \mathrm{O}_{6.1}$ & $\mathrm{Hg}_{0.6} \mathrm{Cr}_{0.4} \mathrm{Ba}_{2} \mathrm{CaCu}_{2}$ & 3.8753 & 12.488 & $110 \mathrm{~K}$ \\
\hline $\mathrm{Hg}_{0.8} \mathrm{Bi}_{0.2} \mathrm{Ba}_{2}(\mathrm{Ca} . \mathrm{Y}) \mathrm{Cu}_{2} \mathrm{O}_{6}$ & $\mathrm{Hg}_{0.8} \mathrm{Bi}_{0.2} \mathrm{Ba}_{2}(\mathrm{Ca} . \mathrm{Y}) \mathrm{Cu}_{2}$ & 3.8536 & 12.583 & $128 \mathrm{~K}$ \\
\hline $\mathrm{Hg}_{0.8} \mathrm{Mn}_{0.2} \mathrm{Ba}_{2} \mathrm{CaCu}_{2} \mathrm{O}_{6.2}$ & $\mathrm{Hg}_{0.7} \mathrm{Mn}_{0.3} \mathrm{Ba}_{2} \mathrm{CaCu}_{2}$ & 3.6888 & 12.480 & $119 \mathrm{~K}$ \\
\hline $\mathrm{Hg}_{0.8} \mathrm{Ge}_{0.2} \mathrm{Ba}_{2} \mathrm{CaCu}_{2} \mathrm{O}_{6.2}$ & $\mathrm{Hg}_{0.8} \mathrm{Ge}_{0.2} \mathrm{Ba}_{2} \mathrm{CaCu}_{2}$ & 3.8565 & 12.599 & $127 \mathrm{~K}$ \\
\hline \multicolumn{5}{|l|}{ "1223"-structure } \\
\hline $\mathrm{HgBa}_{2} \mathrm{Ca}_{2} \mathrm{Cu}_{3} \mathrm{O}_{8+\delta}$ & $-\cdots$ & 3.8564 & 15.856 & $105 \mathrm{~K}$ \\
\hline $\mathrm{Hg}_{0.8} \mathrm{~V}_{0.2} \mathrm{Ba}_{2} \mathrm{Ca}_{2} \mathrm{Cu}_{3} \mathrm{O}_{8.3}$ & $\mathrm{Hg}_{0.7} \mathrm{~V}_{0.3} \mathrm{Ba}_{2} \mathrm{Ca}_{2} \mathrm{Cu}_{3}$ & 3.8629 & 15.652 & $120 \mathrm{~K}$ \\
\hline $\mathrm{Hg}_{0.8} \mathrm{Mo}_{0.2} \mathrm{Ba}_{2} \mathrm{Ca}_{2} \mathrm{Cu}_{3} \mathrm{O}_{8.4}$ & $\mathrm{Hg}_{0.75} \mathrm{Mo}_{0.25} \mathrm{Ba}_{2} \mathrm{Ca}_{2} \mathrm{Cu}_{3}$ & 3.8537 & 15.731 & $129 \mathrm{~K}$ \\
\hline $\mathrm{Hg}_{0.6} \mathrm{Ti}_{0.4} \mathrm{Ba}_{2} \mathrm{Ca}_{2} \mathrm{Cu}_{3} \mathrm{O}_{8.4}$ & $\mathrm{Hg}_{0.7} \mathrm{Ti}_{0.3} \mathrm{Ba}_{2} \mathrm{Ca}_{2} \mathrm{Cu}_{3}$ & 3.8507 & 15.707 & $128 \mathrm{~K}$ \\
\hline $\mathrm{Hg}_{0.8} \mathrm{Cr}_{0.2} \mathrm{Ba}_{2} \mathrm{Ca}_{2} \mathrm{Cu}_{3} \mathrm{O}_{8.1}$ & $\mathrm{Hg}_{0.6} \mathrm{Cr}_{0.4} \mathrm{Ba}_{2} \mathrm{Ca}_{2} \mathrm{Cu}_{3}$ & 3.8631 & 15.625 & $95 \mathrm{~K}$ \\
\hline $\mathrm{Hg}_{0.8} \mathrm{Bi}_{0.2} \mathrm{Ba}_{2} \mathrm{Ca}_{2} \mathrm{Cu}_{3} \mathrm{O}_{8.2}$ & $\mathrm{Hg}_{0.8} \mathrm{Bi}_{0.2} \mathrm{Ba}_{2} \mathrm{Ca}_{2} \mathrm{Cu}_{3}$ & 3.8631 & 15.813 & $130 \mathrm{~K}$ \\
\hline
\end{tabular}


For $\mathrm{M}=\mathrm{Cu}, \mathrm{Ca}, \mathrm{Bi}, \mathrm{Tl}, \mathrm{Pb}, \mathrm{Cr}$, and $\mathrm{Mo}$, the electron diffraction study and the HREM images indicate a perovskite cell periodicity with parameter: $a_{\mathrm{p}} \approx 3.8 \AA$. At the level of the mixed layer, no variation nor modulation of the contrast is observed indicating a statistical distribution of mercury and $\mathrm{M}$ cations on the same crystallographic site.

The situation is different for praesodymium, cerium and strontium compounds. For the 1201 compound, $\mathrm{Hg}_{0.4} \mathrm{Pr}_{0.6} \mathrm{Sr}_{2-y} \mathrm{Pr}_{y} \mathrm{CuO}_{4+\delta}$ [15], an orthorhombic cell is observed with $a=2 a_{\mathrm{p}}$, $b=a_{\mathrm{p}}$ and $c=c_{1201}$ (Fig. 2b). The HREM images (Fig. 2a) show a very regular variation of the contrast at the level of the "mercury" layers, where one grey dot alternates with one bright dot along a. This effect is correlated to an ordering of the $\mathrm{Hg}$ and $\mathrm{Pr}$ atoms in the mercury layer in such a way that one mercury row alternates with one praesodymium row along a (Fig. $2 \mathrm{~b}$ ). The simulated images show that the variations in the cation environment, i.e. the oxygen positions, are mostly involved in the contrast variations. In the 1212 oxides, $\mathrm{Hg}_{0.4} \mathrm{Pr}_{0.6} \mathrm{Sr}_{2} \mathrm{Sr}_{1-x} \operatorname{Pr}_{x} \mathrm{Cu}_{2} \mathrm{O}_{6+\delta}$ [21], two kinds of ordering are observed for the same composition. The first type, termed orthorhombic I, exhibits a doubling of the cell with $a_{\mathrm{I}}=2 a_{\mathrm{p}}, b_{\mathrm{I}}=a_{\mathrm{p}}$ and $c_{\mathrm{I}}=c_{1212}$ whereas the second, termed orthorhombic II, corresponds to a doubling of the $a$ and $c$ parameters, $a_{\mathrm{II}}=2 a_{\mathrm{p}}, b_{\mathrm{II}}=a_{\mathrm{p}}$ and $c_{\text {II }}=2 c_{1212}$; the [010] ED patterns of the two types are given in Figures $3 \mathrm{a}$ and $4 \mathrm{a}$, respectively. The corresponding HREM images (Figs. $3 \mathrm{~b}$ and $4 \mathrm{~b}$ ) clearly show the ordering phenomenon which takes place at the level of the mercury layer. One observes, as for the 1201's, that one row of mercury alternates with one row of praesodymium along a; in the orthorhombic $\mathrm{I}\left(\mathrm{O}_{\mathrm{I}}\right)$, two successive rows of mercury are aligned along $\mathbf{c}$ so that the $c$ parameter, $c_{1212}$, remains unchanged (Fig. $3 \mathrm{c}$ ), whereas in the orthorhombic II $\left(\mathrm{O}_{\mathrm{II}}\right)$, successive rows are shifted by $a_{\mathrm{II}} / 2$, leading to a doubling of the $c_{1212}$ parameter (Fig. 4c). The theoretical images, calculated on the basis of the two structural hypotheses, confirm this interpretation.

To understand the different parameters which govern the ordering mechanisms in these oxides, a third member of the cuprate family was prepared [31], keeping unchanged the cationic composition of the mixed layer, $\mathrm{Hg}_{0.4} \mathrm{Pr}_{0.6} \mathrm{Sr}_{2} \mathrm{Sr}_{0.3} \mathrm{Pr}_{1.7} \mathrm{Cu}_{2} \mathrm{O}_{8+\delta}$. This cuprate exhibits a 1222-type structure i.e. the $\left[\mathrm{Sr}_{1-x} \mathrm{Pr}_{x}\right]$ oxygen deficient layer located between the two pyramidal copper layers is replaced by a double [ $\left.\mathrm{Sr}_{2-x} \mathrm{Pr}_{x} \mathrm{O}_{2}\right]$ fluorite-type layer (Fig. 5a). In that way, the two structures exhibit a very close relationship but they differ by the distance between two successive ordered planes which is approximately $15 \AA$ in 1222 , larger than for the previous compounds (12 $\AA$ for 1212 and $9 \AA$ for 1201). High resolution images along the [010] section directly reveal the ordering. In Figure 5b, the copper configuration is imaged as intense bright dots while the double Pr-Pr layer in between the two $\mathrm{Cu}$ layers is imaged as an almost continuous dark band. The $\left[(\mathrm{Hg}, \mathrm{Pr}) \mathrm{O}_{\delta}\right]$ plane is characterized in this contrast by a series of heavy dark dots, separated by approximately $2 a_{\mathrm{p}}=7.6 \AA$. According to the simulations, these dark dots image the Pr configuration within the mixed plane. Two remarks could be made here. First, the $2 a_{\mathrm{p}}$ periodicity is no longer respected over large distances as a result of the existence of an antiphase shift which occurs within the $\left[(\mathrm{Hg}, \mathrm{Pr}) \mathrm{O}_{\delta}\right]$ plane (see white arrowheads in Fig. 5b). Second, because of the presence of the double [ $\mathrm{Sr}_{2-x} \mathrm{Pr}_{x} \mathrm{O}_{2}$ ] fluorite-type layer in the basic 1222 structure, equivalent $\mathrm{Pr}$ (or $\mathrm{Hg}$ ) positions cannot be aligned along $\mathrm{c}$ in subsequent $\left[(\mathrm{Hg}, \mathrm{Pr}) \mathrm{O}_{\delta}\right]$ planes; they are necessarily shifted by $1 / 2 a_{\mathrm{p}}$ or $-1 / 2 a_{\mathrm{p}}$. We can observe that the $\mathrm{Hg} / \mathrm{Pr}$ ordering does occur within a single $\left[(\mathrm{Hg}, \mathrm{Pr}) \mathrm{O}_{\delta}\right]$ plane, but the correlation between successive $\left[(\mathrm{Hg}, \mathrm{Pr}) \mathrm{O}_{\delta}\right]$ planes is virtually completely lost. The relation between the ordering in successive $\left[(\mathrm{Hg}, \mathrm{Pr}) \mathrm{O}_{\delta}\right]$ planes is random and hence it is impossible to maintain an orthorhombic cell as in the basic 1222 structure. We therefore have to describe the structure as triclinic with unit cell parameters $a_{\mathrm{t}}=2 a_{\mathrm{p}}, b_{\mathrm{t}}=b_{\mathrm{p}}$, $c_{\mathrm{t}}=1 / 2\left(c_{1222}+a_{\mathrm{p}}+b_{\mathrm{p}}\right)$ and angles $82.9^{\circ}, 82.9^{\circ}$ and $90^{\circ}$ respectively. The defect due to the lack of correlation between two successive layers can be described as nano-scale twinning. 


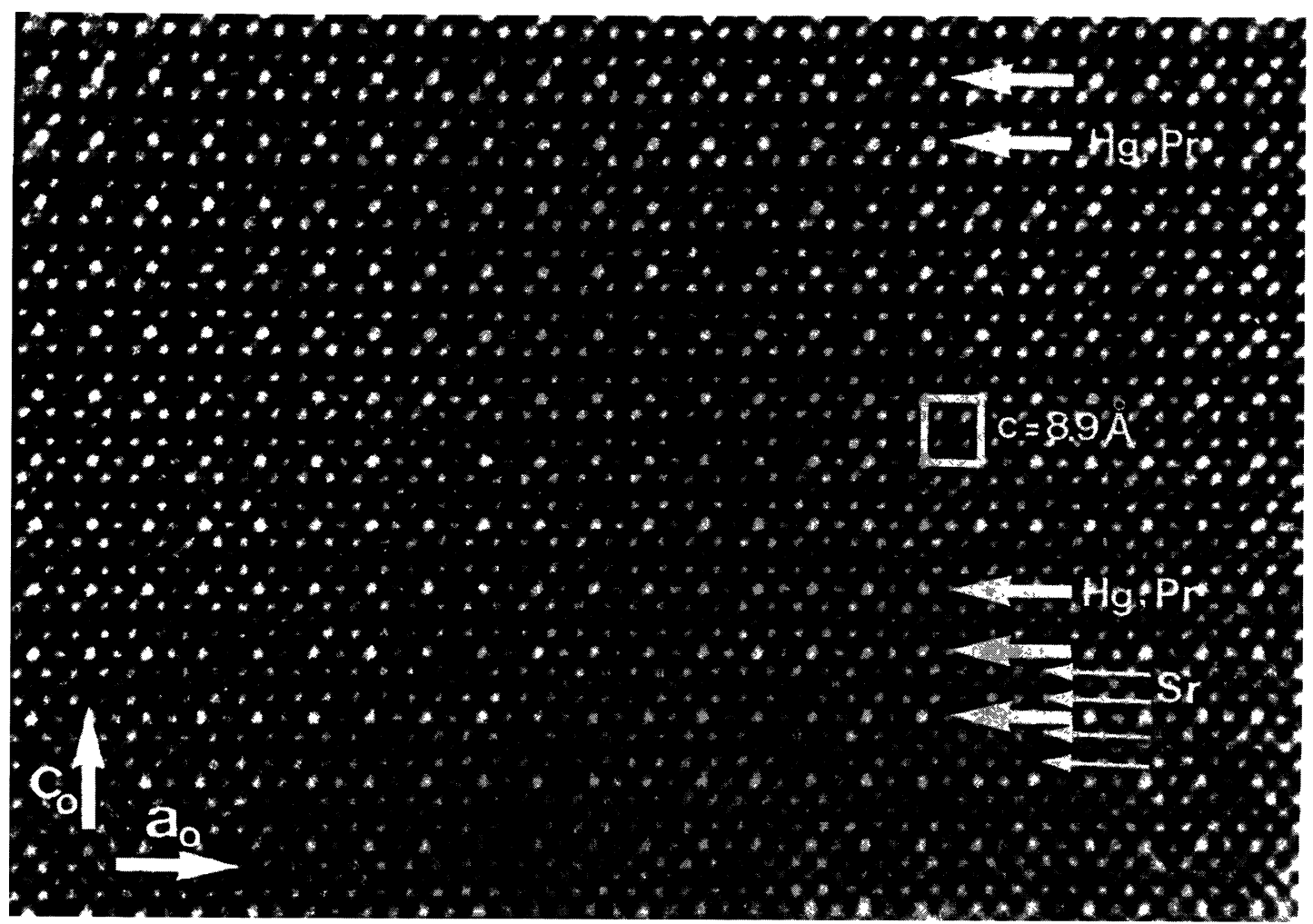

a)

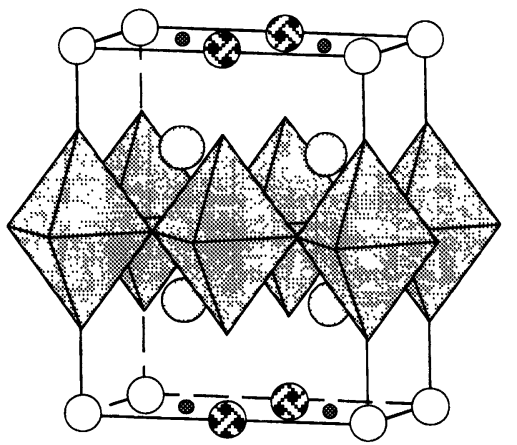

$\mathrm{Hg}_{0.5} \mathrm{Pr}_{0.5} \mathrm{O}_{\delta}$

$\mathrm{SrO}$

$\mathrm{CuO}_{2}$

$\mathrm{SrO}$

$\mathrm{Hg}_{0.5} \mathrm{Pr}_{0.5} \mathrm{O}_{\delta}$

b)

Fig. 2. - Othorhombic ordered $1201 \mathrm{Hg}_{0.4} \operatorname{Pr}_{0.6} \mathrm{Sr}_{2-y} \operatorname{Pr}_{y} \mathrm{CuO}_{4+\delta}: \mathrm{a}$ )[100] HREM image showing the contrast variation at the level of the mixed $\mathrm{Hg} / \mathrm{Pr}$ layer and $\mathrm{b}$ ) idealized model of the ordered structure with $a=2 a_{\mathrm{p}}$.

For the $\mathrm{Hg} / \mathrm{Pr}$ barium based compounds, the $\mathrm{Hg} / \mathrm{Pr}$ ratio within a mixed layer is significantly lower; as an example, it is close to 5 in the 2212 cuprate $\mathrm{Hg}_{1.5} \mathrm{Ba}_{2} \mathrm{Pr}_{1.3} \mathrm{Cu}_{2.2} \mathrm{O}_{8-\delta}$ [32] and in the 2222 cuprate $\mathrm{Hg}_{1.5} \mathrm{Ba}_{2} \mathrm{Pr}_{2.3} \mathrm{Cu}_{2.2} \mathrm{O}_{10-\delta}$ [33], compared to $2 / 3$ in the strontium based compounds (1201, 1212 or 1222's). These two structures can be described starting from the 1212 and 1222 


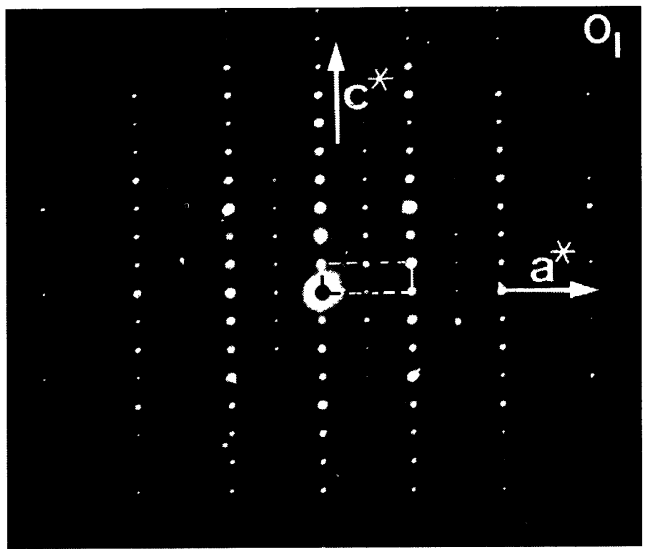

a)
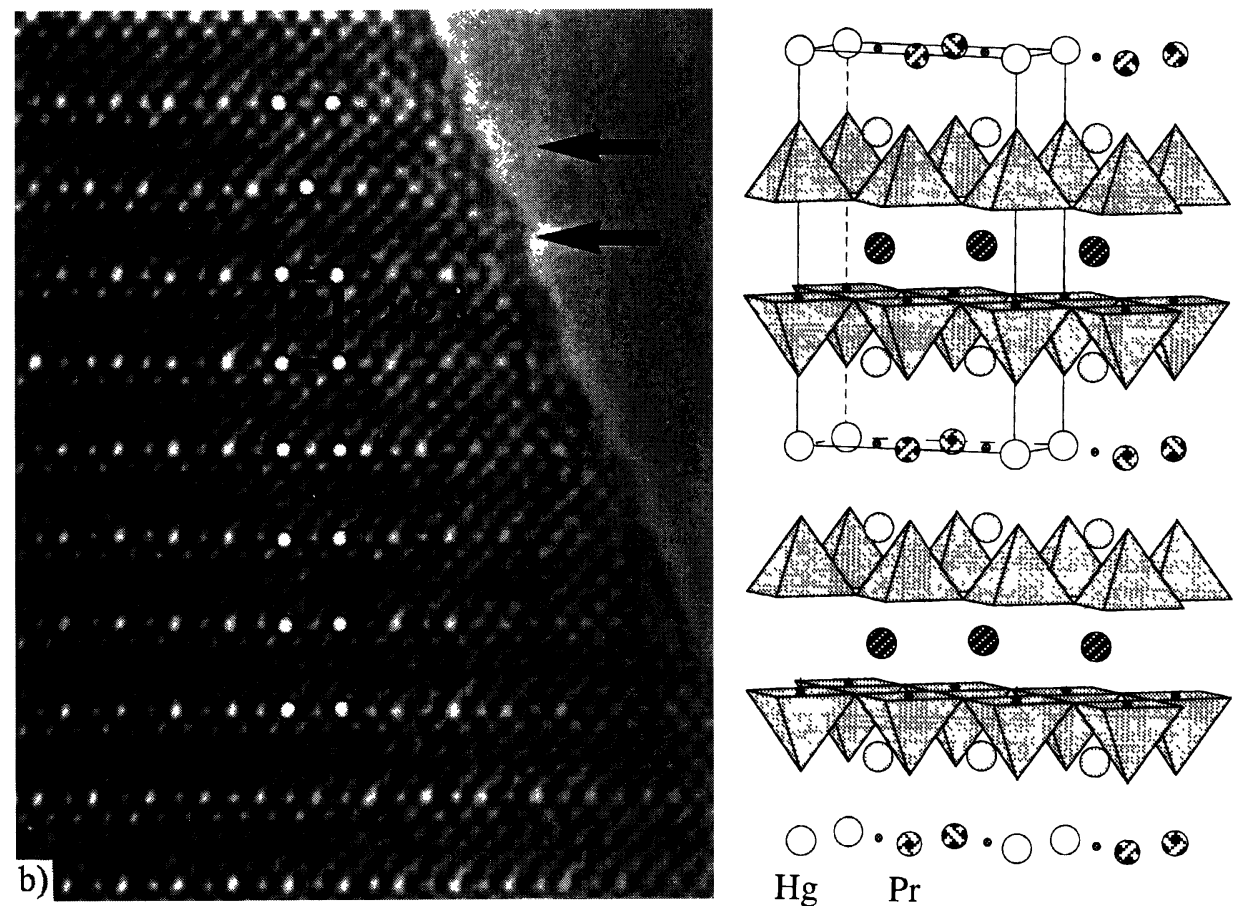

$\mathrm{Hg}_{0.5} \mathrm{Pr}_{0.5} \mathrm{O}_{\delta}$

$\mathrm{SrO}$

$\mathrm{CuO}_{2}$ $\mathrm{A}_{1-\mathrm{x}} \mathrm{Pr}_{\mathrm{x}}$

$\mathrm{CuO}_{2}$

$\mathrm{SrO}$

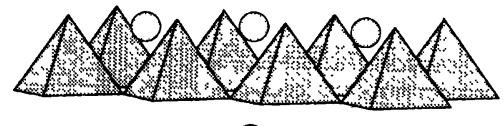

$\therefore \bigcirc$

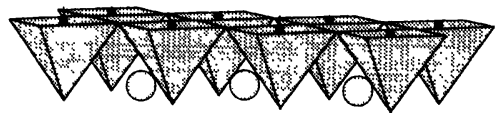

$\bigcirc \bigcirc \cdot \bullet \cdot \bigcirc 0 \cdot 00$

$\mathrm{Hg} \quad \mathrm{Pr}$

Fig. 3. - $\mathrm{O}_{\mathrm{I}}$-structure of the $1212 \mathrm{Hg}_{0.4} \mathrm{Sr}_{2.7} \mathrm{Pr}_{0.9} \mathrm{Cu}_{2} \mathrm{O}_{7}$ : a) [010] ED pattern, b) HREM image and c) idealized model.

structures by only adding a mercury layer in the rock salt "slice" (Figs. 6a and b). The high regularity of the contrast at the level of the mixed layers is illustrated for the 2222's in Figure 6c where the positions of the cations are imaged as intense bright dots (the nature of the different layers is identified in the left part of the micrograph): a very regular contrast is observed at the level of the mercury layers so that we can assume a statistical distribution of the $\mathrm{Hg}$ and $\mathrm{Pr}$ atoms within the mixed planes. 


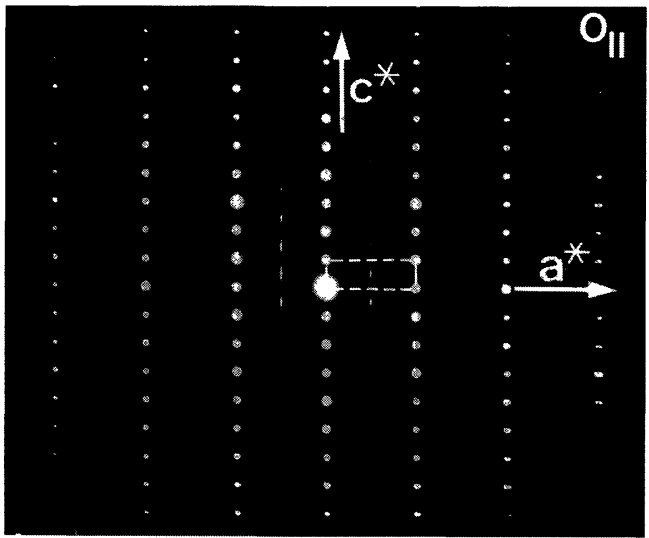

a)

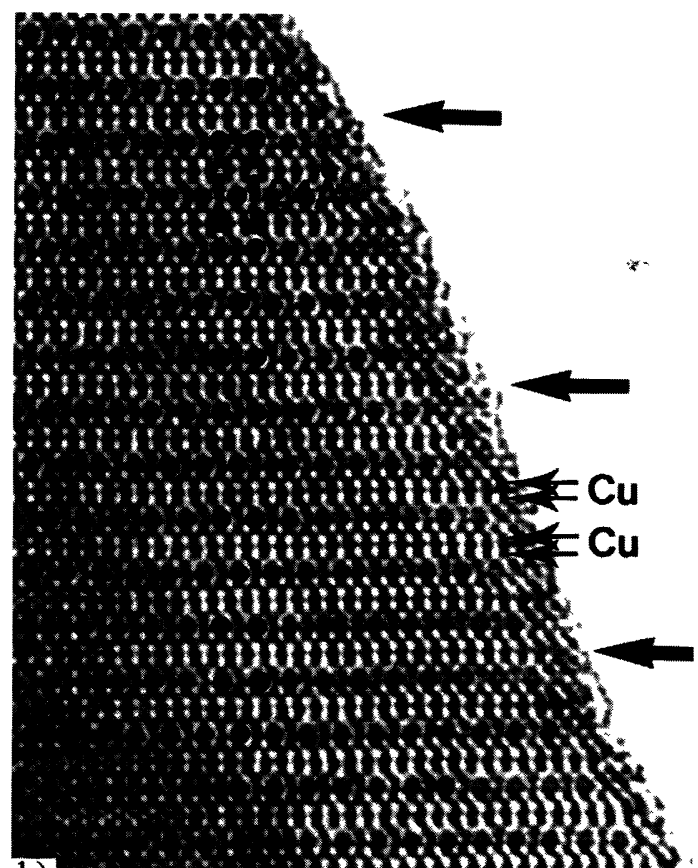

b)

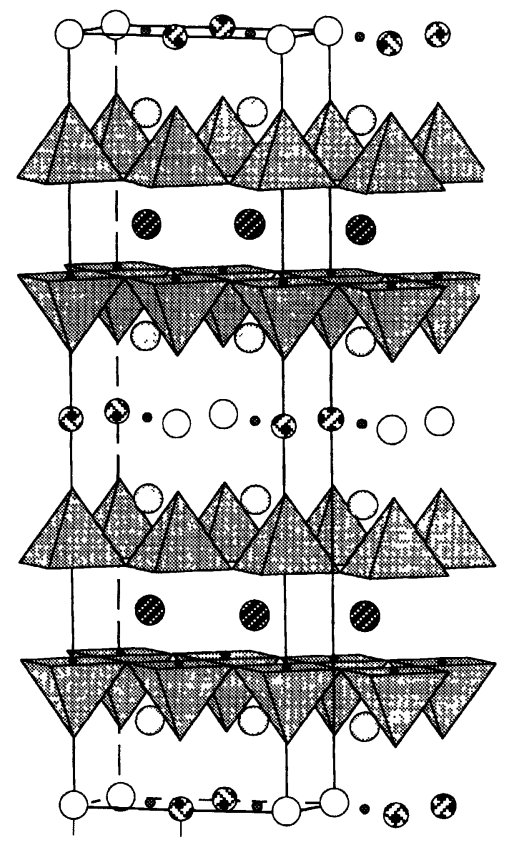

$\mathrm{Hg}_{0.5} \operatorname{Pr}_{0.5} \mathrm{O}_{\delta}$

$\mathrm{SrO}$

$\mathrm{CuO}_{2}$ $\mathrm{A}_{1-\mathrm{x}} \mathrm{Pr}_{\mathrm{x}}$

$\mathrm{CuO}_{2}$

$\mathrm{SrO}$

Fig. 4. $-\mathrm{O}_{\mathrm{II}}$-structure of the $1212 \mathrm{Hg}_{0.4} \mathrm{Sr}_{2.7} \mathrm{Pr}_{0.9} \mathrm{Cu}_{2} \mathrm{O}_{7}$ : a) [010] ED pattern, b) HREM image and c) idealized model.

1.3 Physical Properties. - As mentioned here above, the structure of the substituted mercury barium cuprates $\left[\mathrm{Hg}_{1-x} \mathrm{M}_{x}\right] \mathrm{Ba}_{2} \mathrm{Ca}_{m-1} \mathrm{Cu}_{m} \mathrm{O}_{2 m+2+\delta}$ is similar to that of the undoped oxides; they only differ by the oxygen content of the mercury layer. The structural evolution is very similar in the 1201, 1212 and 1223 series. An anisotropy effect is observed, with a collapsing of the $c$ parameter whose amplitude depends on the nature and the content $x_{s}$ of the cation M. One of the most important result of the investigation of the superconducting properties of these 


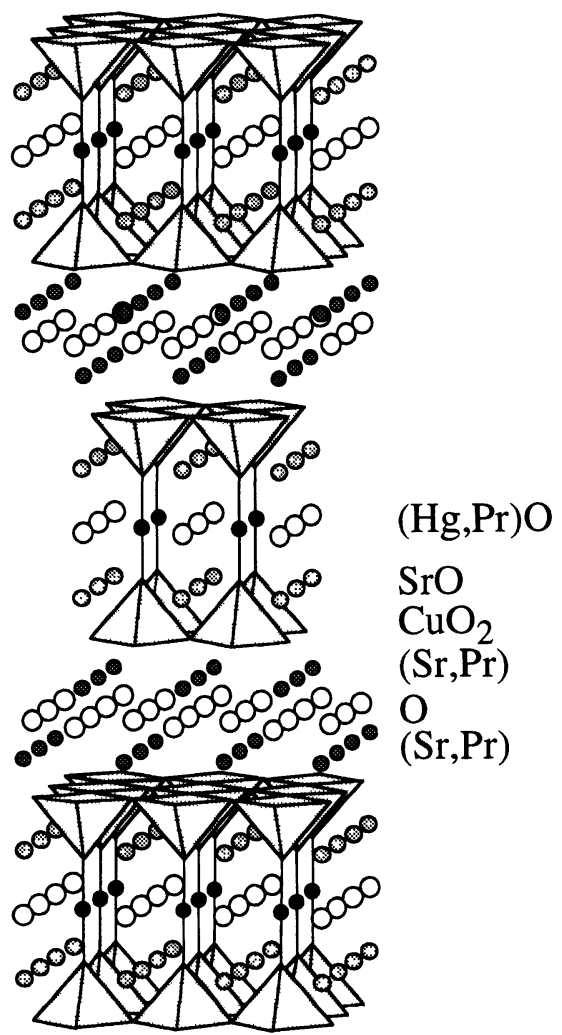

a)

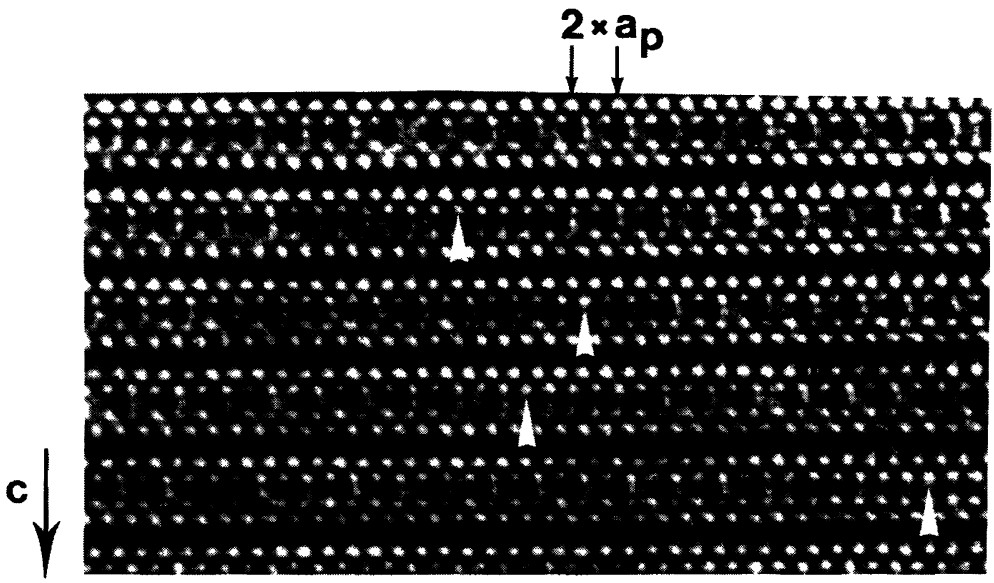

b)

Fig. 5. $-\mathrm{Hg}_{0.4} \mathrm{Pr}_{0.6} \mathrm{Sr}_{2.3} \mathrm{Pr}_{1.7} \mathrm{Cu}_{2} \mathrm{O}_{9}$ : a) idealized model of the 1222 structure and $\mathrm{b}$ ) HREM image showing the partial ordering of the cations within the mixed layer.

cuprates [25-30] deals with the fact that a great number of these new superconductors exhibit very performant characteristics, i.e. similar critical temperatures (with regard to the undoped materials) and good superconducting volume fractions (40\% to 90\%) (Tabs. I and II). 


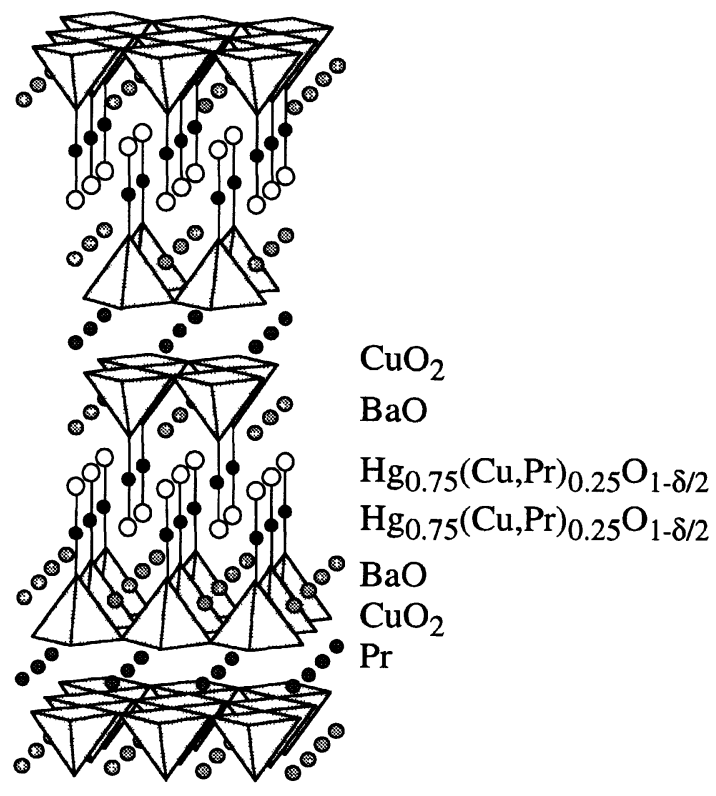

a)

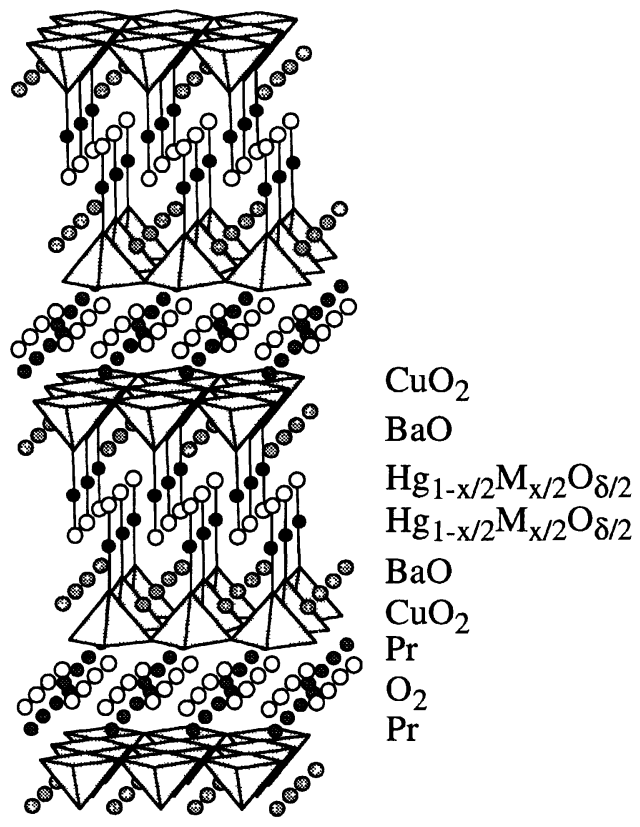

b)

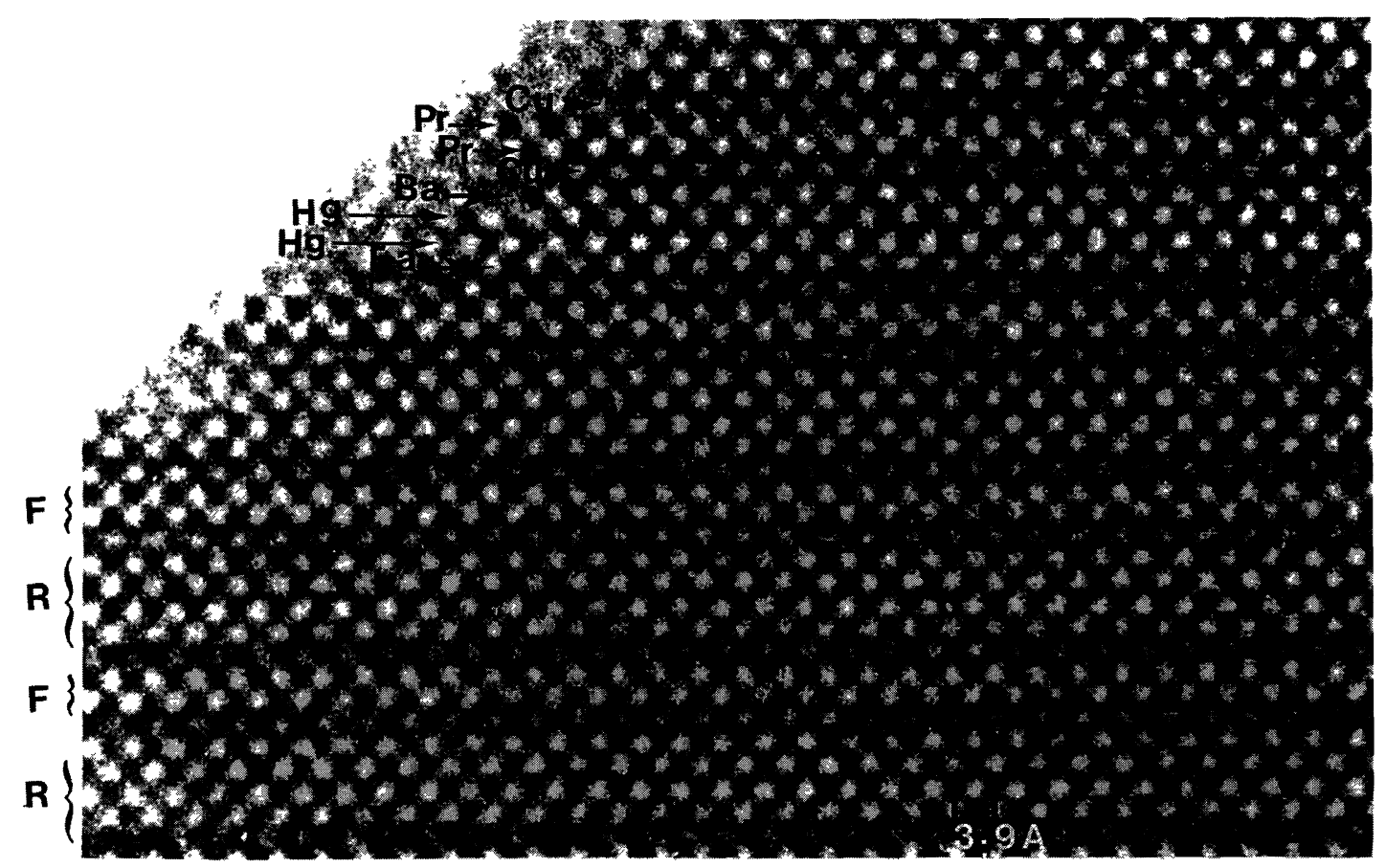

c)

Fig. 6. - Idealized structures of the a) 2212's, b) 2222's and c) HREM image of a 2222 mercury praseodymium oxide. No contrast variation is observed at the level of the mixed layers. 
For the strontium based 1201 and 1212 cuprates, $\left[\mathrm{Hg}_{1-x} \mathrm{M}_{x}\right] \mathrm{Sr}_{2} \mathrm{Ca}_{m-1} \mathrm{Cu}_{m} \mathrm{O}_{2 m+2+\delta}$, critical temperatures ranging from 27 to $95 \mathrm{~K}$ have been observed with good superconducting volume fractions. These temperatures are, in a general way, lower than those observed in the mercury barium based oxides; this effect can be compared to that observed in the thallium based superconductors. The most spectacular feature of these materials deals with the superconducting properties of the praesodymium 1212 mercury cuprates that exhibit a critical temperature up to $85 \mathrm{~K}$ as, for instance, for the praseodymium rich phase $\mathrm{Hg}_{0.4} \mathrm{Pr}_{0.6} \mathrm{Sr}_{2.7} \mathrm{Pr}_{0.3} \mathrm{Cu}_{2} \mathrm{O}_{6+\delta}$ for which a very high diamagnetic volume fraction (90\%) and a sharp transition are observed. This effect of $\mathrm{Pr}$ which enhances dramatically the superconducting properties of the 1212 phase, and increases especially Tc's is fundamentally opposite to what is observed for other cuprates such as the " 123 " phase in which the introduction of Pr kills superconductivity.

\section{Superconducting Oxycarbonates}

Introducing carbonate groups in the perovskite related structures of the copper oxides is another rather recently recognized structural mechanism. It results in the formation of new phases, called the "copper oxycarbonates", which exhibit original structures and very interesting physical properties. Several recently discovered structural families have been isolated, which can be differentiated by the composition of the layer where the carbonate groups are inserted. "Pure" carbonate layers are only built up from carbonate groups whereas "mixed" layers are built up from the coexistence of copper-oxygen or metal-oxygen polyhedra and carbonate groups; both are sandwiched between two [AO] layers.

2.1 The Parent Structures with Pure Carbonate Layers. - The simplest structure of the strontium based copper oxycarbonate $\mathrm{Sr}_{2} \mathrm{CuO}_{2} \mathrm{CO}_{3}$ [34], can be simply described from the ordered substitution of one $\left[\mathrm{CuO}_{2}\right]$ layer by a $[\mathrm{CO}]_{\infty}$ layer every two units in a perovskite framework (Fig. 7a). This mechanism was applied to the layered superconducting cuprates.

According to this mechanism, two families are generated which are built up from the intergrowth of one $1201\left(\mathrm{ASr}_{2} \mathrm{CuO}_{5}\right)$ or $2201\left(\mathrm{Bi}_{2} \mathrm{Sr}_{2} \mathrm{CuO}_{6}\right)$ unit with one, or more, $\mathrm{S}_{2} \mathrm{CC}$ units. They can be expressed by the general formula $[1201]_{m}\left[\mathrm{Sr}_{2} \mathrm{CuO}_{2} \mathrm{CO}_{3}\right]_{n}[35-41]$ or $[2201]_{m}\left[\mathrm{Sr}_{2}\right.$ $\left.\mathrm{CuO}_{2} \mathrm{CO}_{3}\right]_{n}$ [42-48], respectively; the members $m=1 / n=1$ are drawn in Figures $7 \mathrm{~b}$ and c, respectively.' The 2201 members are only bismuth based whereas in the 1201, the metallic sites of the intermediate layer are occupied by thallium, lead, mercury, bismuth or "mixed cations" as reported in the first section. The members corresponding to $n=1,2$ and 3 have been isolated (Tab. III).

The first HREM studies showed that carbonate groups give rise to a very typical contrast for several focus values, such as $-20,-50$ and $-85 \mathrm{~nm}$ (for $V=200 \mathrm{kV}$ and Cs $=0.4 \mathrm{~mm}$ and crystal thickness $\approx 30 \AA$ ). One example is given in Figure 8 for the oxycarbonate $\mathrm{Pb}_{0.7} \mathrm{Hg}_{0.3} \mathrm{Sr}_{4} \mathrm{Cu}_{2} \mathrm{CO}_{3}$ $\mathrm{O}_{7-\delta}$ where the intense bright dots are correlated to the light electron density zones. In the HREM images, the carbonate layers are characterized by a triple row of bright dots which is correlated to the oxygen atoms belonging to the triple layer [(SrO)(CO)(SrO)] (Fig. 7b). Two other examples are given in Figures $9 \mathrm{a}$ and $\mathrm{b}$, for the members $n=2$ and 3 of the bismuth oxycarbonates, respectively. In Figure 9a, the bismuth layers are imaged as two rows of dark dots and the two carbonate layers as two rows of bright dots (they are indicated by curved arrows). The sequence of the layer stacking along the $\mathbf{c}$ axis appears very clearly; such a structure can thus be described from the intergrowth of one 2201 unit, $\mathrm{Bi}_{2} \mathrm{Sr}_{2} \mathrm{CuO}_{6}$, with two $\mathrm{Sr}_{2} \mathrm{CuO}_{2} \mathrm{CO}_{3}$ units (Fig. 7d). The member $n=3,\left[\mathrm{Bi}_{2} \mathrm{Sr}_{2} \mathrm{CuO}_{6}\right]_{1}\left[\mathrm{Sr}_{2} \mathrm{CuO}_{2} \mathrm{CO}_{3}\right]_{3}$, was also isolated. As usually observed in series built up from the intergrowth of two structural units, the higher members are often 


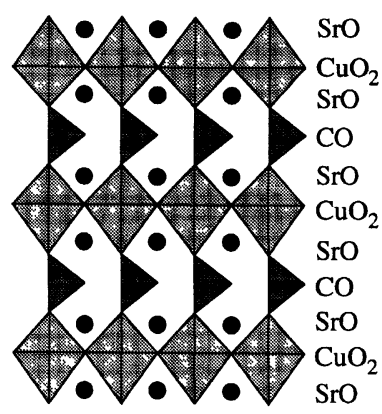

a)
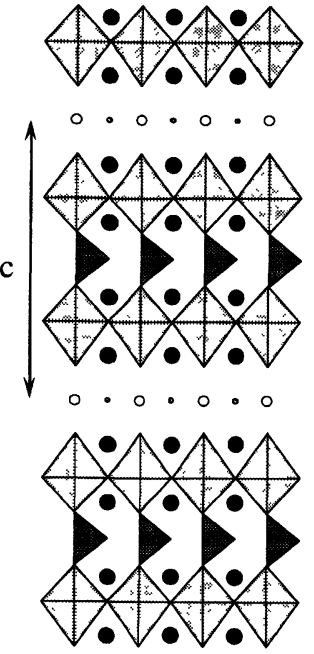

b)

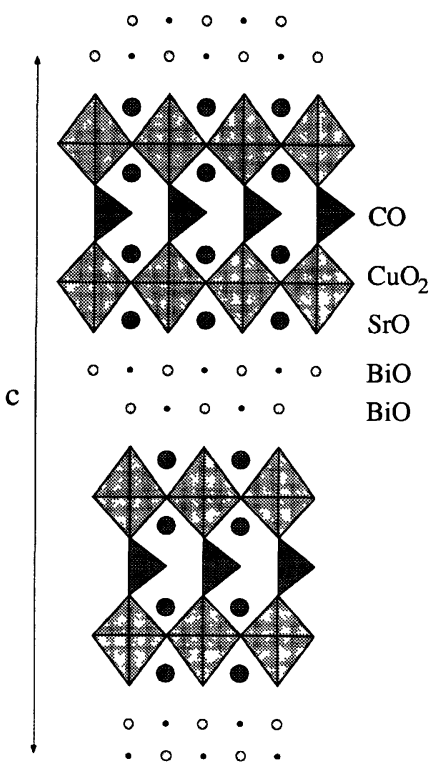

c)

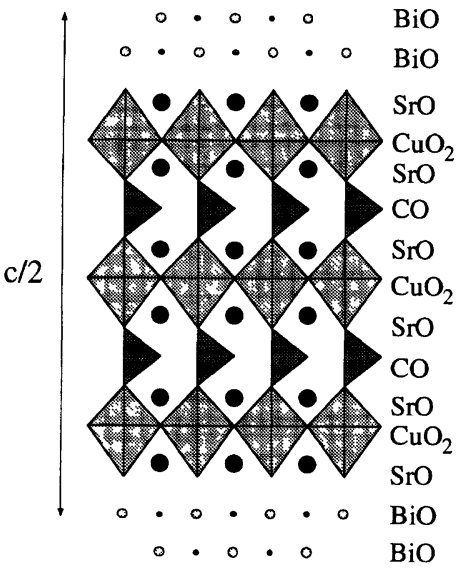

d)

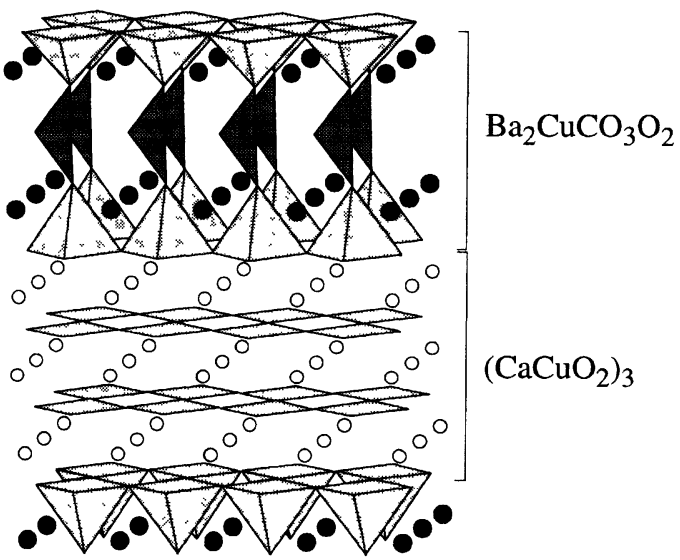

e)

Fig. 7. - Idealized models of: a) $\mathrm{Sr}_{2} \mathrm{CuO}_{2} \mathrm{CO}_{3}$, b) [1201 $]_{1}\left[\mathrm{Sr}_{2} \mathrm{CuO}_{2} \mathrm{CO}_{3}\right]_{1}$, c) $[2201]_{1}\left[\mathrm{Sr}_{2} \mathrm{CuO}_{2} \mathrm{CO}_{3}\right]_{1}$, d) $[2201]_{1}\left[\mathrm{Sr}_{2} \mathrm{CuO}_{2} \mathrm{CO}_{3}\right]_{2}$ and e) $\left[\mathrm{CaCuO}_{2}\right]_{3}\left[\mathrm{Ba}_{2} \mathrm{CuO}_{2} \mathrm{CO}_{3}\right]_{1}$ structures.

suffering from intergrowth defects. One example is given in Figure 10a where $n$ members as high as 10 are observed. The calculated images confirm this interpretation and so the carbonate layers can be easily identified. An example is given in Figure $10 \mathrm{~b}$ for the $n=2$ member of the bismuth family. For a focus value close to $-20 \mathrm{~nm}$ the bismuth positions appear as dark dots (straight arrows) and the carbon positions as grey dots surrounded by bright dots (curved arrows). 
Table III. - Characteristics of the oxycarbonates.

\begin{tabular}{|c|c|c|c|c|c|}
\hline \multirow[t]{2}{*}{ Composition } & \multicolumn{4}{|c|}{ Cell parameters } & \multirow{2}{*}{$\begin{array}{c}\text { Tc } \\
\text { (onset) }\end{array}$} \\
\hline & a $(\AA)$ & b ( $(\AA)$ & c $(\AA)$ & $\beta\left({ }^{\circ}\right)$ & \\
\hline \multicolumn{6}{|l|}{ "123" derivatives } \\
\hline $\mathrm{Y}_{1.6} \mathrm{Ca}_{0.4} \mathrm{Ba}_{4} \mathrm{Cu}_{5} \mathrm{O}_{11} \mathrm{CO}_{3}$ & 7.77 & 3.89 & 22.98 & & N.S. \\
\hline $\mathrm{YCaBa}_{4} \mathrm{Cu}_{5} \mathrm{O}_{11}\left(\mathrm{CO}_{3}\right)_{1-\mathrm{x}}\left(\mathrm{NO}_{3}\right)_{\mathrm{X}}$ & 7.76 & 3.885 & 23.07 & & $82 \mathrm{~K}$ \\
\hline $\mathrm{Y}_{3} \mathrm{Ba}_{6} \mathrm{Cu}_{8} \mathrm{O}_{18} \mathrm{CO}_{3}$ & 11.57 & 3.885 & 23.17 & & N.S. \\
\hline $\mathrm{Y}_{4} \mathrm{Sr}_{5} \mathrm{Cu}_{11} \mathrm{O}_{25} \mathrm{CO}_{3}$ & 15.31 & 3.85 & 22.37 & & N.S. \\
\hline \multicolumn{6}{|l|}{ "classical" oxycarbonates } \\
\hline $\mathrm{Hg}_{0 .} \mathrm{Bi}_{0.5} \mathrm{Sr}_{4} \mathrm{Cu}_{2} \mathrm{O}_{7} \mathrm{CO}_{3}$ & 3.827 & & 16.47 & & $17 \mathrm{~K}$ \\
\hline $\mathrm{Hg}_{0.4} \mathrm{Cr}_{0.6} \mathrm{Sr}_{4} \mathrm{Cu}_{2} \mathrm{O}_{7} \mathrm{CO}_{3}$ & 3.875 & & 16.155 & & $37 \mathrm{~K}$ \\
\hline $\mathrm{Hg}_{0.5} \mathrm{Mo}_{0.5} \mathrm{Sr}_{4} \mathrm{Cu}_{2} \mathrm{O}_{7} \mathrm{CO}_{3}$ & 3.845 & & 16.317 & & $74 \mathrm{~K}$ \\
\hline $\mathrm{Hg}_{0.6} \mathrm{~V}_{0.4} \mathrm{Sr}_{4} \mathrm{Cu}_{2} \mathrm{O}_{7} \mathrm{CO}_{3}$ & 3.850 & & 16.240 & & $76 \mathrm{~K}$ \\
\hline $\mathrm{Hg}_{0.3} \mathrm{~Pb}_{0.7} \mathrm{Sr}_{4} \mathrm{Cu}_{2} \mathrm{O}_{7} \mathrm{CO}_{3}$ & 3.824 & & 16.468 & & $70 \mathrm{~K}$ \\
\hline $\mathrm{Tl}_{0.5} \mathrm{Bi}_{0.5} \mathrm{Sr}_{4} \mathrm{Cu}_{2} \mathrm{O}_{7} \mathrm{CO}_{3}$ & 3.831 & & 16.518 & & $55 \mathrm{~K}$ \\
\hline $\mathrm{Tl}_{0.5} \mathrm{~Pb}_{0.5} \mathrm{Sr}_{4} \mathrm{Cu}_{2} \mathrm{O}_{7} \mathrm{CO}_{3}$ & 3.824 & & 16.516 & & $70 \mathrm{~K}$ \\
\hline $\mathrm{Bi}_{2-\mathrm{x}} \mathrm{Pb}_{\mathrm{x}} \mathrm{Sr}_{4-\mathrm{y}} \mathrm{Cu}_{2} \mathrm{O}_{8} \mathrm{CO}_{3}$ & 5.458 & 5.475 & 39.50 & & $30 \mathrm{~K}$ \\
\hline $\mathrm{Bi}_{2} \mathrm{Sr}_{6-\mathrm{x}} \mathrm{Cu}_{3} \mathrm{O}_{10}\left(\mathrm{CO}_{3}\right)_{2}$ & 5.469 & 5.48 & 54.26 & & $40 \mathrm{~K}$ \\
\hline $\mathrm{Bi}_{2-\mathrm{x}} \mathrm{Pb}_{\mathrm{x}} \mathrm{Sr}_{8} \mathrm{Cu}_{4} \mathrm{O}_{12} \mathrm{CO}_{3}$ & 5.494 & 5.478 & 69.49 & & $34 \mathrm{~K}$ \\
\hline \multicolumn{6}{|l|}{ "collapsed" oxycarbonates } \\
\hline $\mathrm{TlBa}_{x} \mathrm{Sr}_{4-\mathrm{x}} \mathrm{Cu}_{2} \mathrm{O}_{7} \mathrm{CO}_{3}$ & 3.839 & 30.50 & $16.725-16.93$ & & $62 \mathrm{~K}$ \\
\hline $\mathrm{Bi}_{15} \mathrm{Sr}_{29} \mathrm{Cu}_{12} \mathrm{O}_{56}\left(\mathrm{CO}_{3}\right)_{7}$ & 18.796 & 5.486 & 39.506 & 111.67 & N.S. \\
\hline $\mathrm{HgBa}_{2} \mathrm{Sr}_{2} \mathrm{Cu}_{2} \mathrm{O}_{6}+\delta \mathrm{CO}_{3}$ & 5.49 & 24.71 & 16.94 & & $66 \mathrm{~K}$ \\
\hline
\end{tabular}

The bismuth oxycarbonates exhibit incommensurate modulations along the $\mathbf{b}$ axis which can be directly compared to those observed in the 2201, 2212 and 2223 bismuth cuprates. These modulations vary with the $\mathrm{Bi} / \mathrm{Sr}$ ratio and with the $\mathrm{Bi} / \mathrm{Sr}$ and $\mathrm{Bi} / \mathrm{Pb}$ ratios in the lead doped materials. An example is given in Figure 11 for $n=2$; the two rows of carbonate groups are indicated by curved arrows and the modulations of the bismuth layers are clearly observed. In the lead doped samples, the coexistence of "normal" Bi-type and Pb-type modulations are observed along the b axis, varying and disappearing with the lead content $[43,48]$; such a behavior is similar to that observed in the bismuth cuprates.

Another structural family exhibits "pure" carbonate layers, substituting copper layers in a perovskite-type matrix [49]. The structure consists of an intergrowth of one $\mathrm{Ba}_{2} \mathrm{CuO}_{2} \mathrm{CO}_{3}$ unit with $m$ units of the so-called "infinite layer structure", $\mathrm{CaCuO}_{2}$, according to the general formulation $\left(\mathrm{CaCuO}_{2}\right)_{m}\left(\mathrm{Ba}_{2} \mathrm{CuO}_{2} \mathrm{CO}_{3}\right)_{n}$. The main member $\mathrm{Ba}_{2} \mathrm{Ca}_{3} \mathrm{Cu}_{4} \mathrm{CO}_{3} \mathrm{O}_{8}(m=3, n=1)$, consists of double layers of $\mathrm{CuO}_{4}$ groups sandwiched by pyramidal layers and interconnected with layers of $\mathrm{CO}_{3}$ groups (Fig. 7e). It should be noted that these materials are only prepared in thin film by laser ablation and have not been prepared, at the present time, by solid state reactions. 


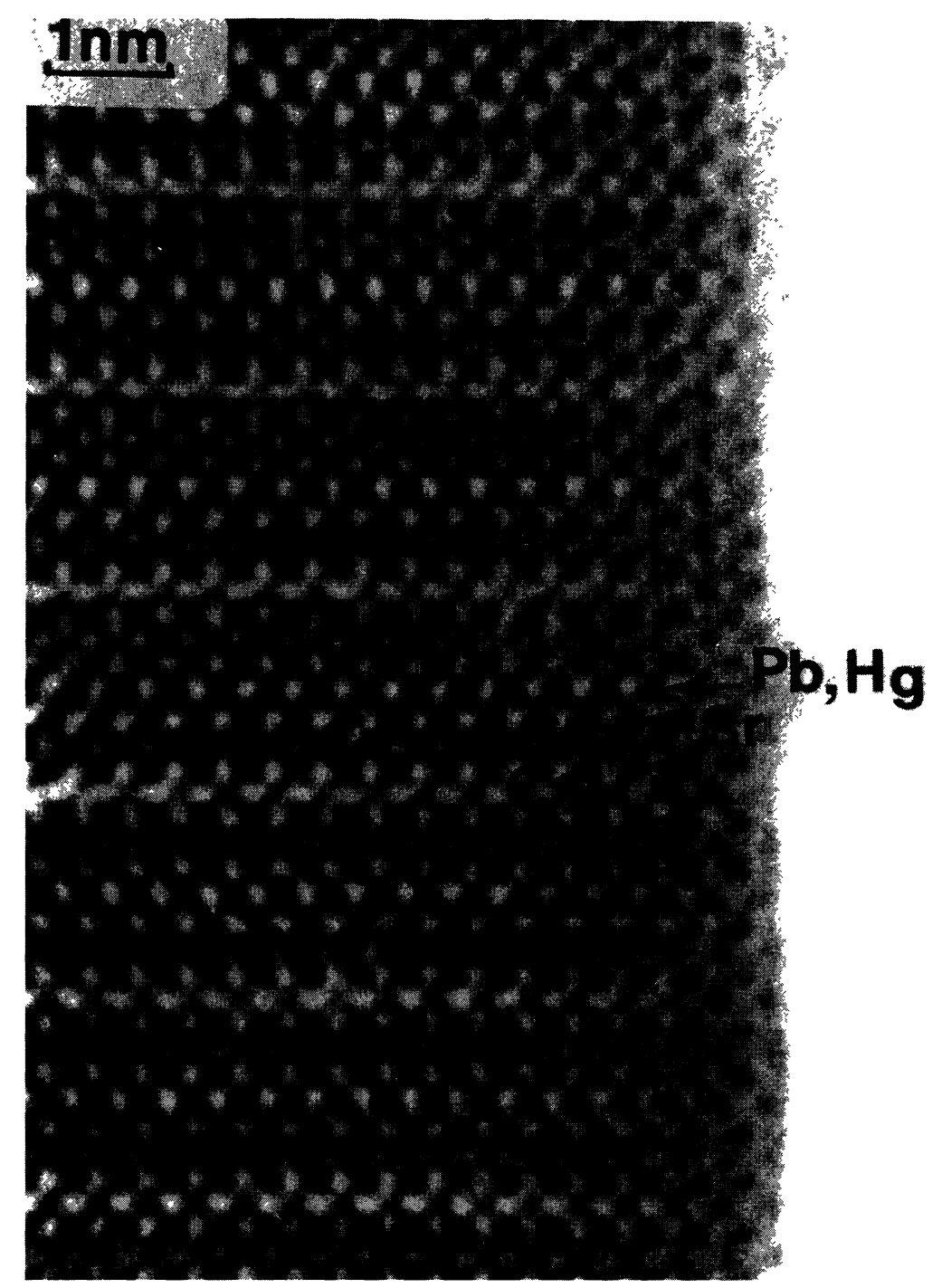

Fig. 8. - HREM image of the [1201] $]_{1}\left[\mathrm{Sr}_{2} \mathrm{CuO}_{2} \mathrm{CO}_{3}\right]_{1}$ oxycarbonate $\mathrm{Hg}_{0.3} \mathrm{~Pb}_{0.7} \mathrm{Sr}_{4} \mathrm{Cu}_{2}\left(\mathrm{CO}_{3}\right) \mathrm{O}_{7}$. The cation positions are imaged as dark dots and the carbonate layer is indicated by a curved arrow.

2.2 Microstructure of the $[1201]_{1}\left[\mathrm{Sr}_{2} \mathrm{CuO}_{2} \mathrm{CO}_{3}\right]_{1}$ Parent Structures. - Generally, the $[1201]_{1}\left[\mathrm{Sr}_{2} \mathrm{CuO}_{2} \mathrm{CO}_{3}\right]_{1}$ oxycarbonates are characterized by a very regular stacking of the layers along the $\mathbf{c}$ axis, in spite of the number of different layers constituting the framework. Among the other defects which have been detected and interpreted in these materials, only two examples will be presented here; they involve structural mechanisms leading to ordering phenomena.

2.2.1 Locally Ordered Substitution of Strontium for Bismuth (or Mercury): the Mixed Layers $\left[(\mathrm{Bi}, \mathrm{Hg})_{2 / 3} \mathrm{Sr}_{1 / 3} \mathrm{O}_{\delta}\right]_{\infty}$. - Parts of the crystals sometimes exhibit superstructures characterized by a tripling of the periodicity along b. [100] HREM images (Fig. 12a) evidence the existence of an ordering phenomenon at the level of the mixed " $\mathrm{Bi}-\mathrm{Hg}$ " layer. This feature is only locally 


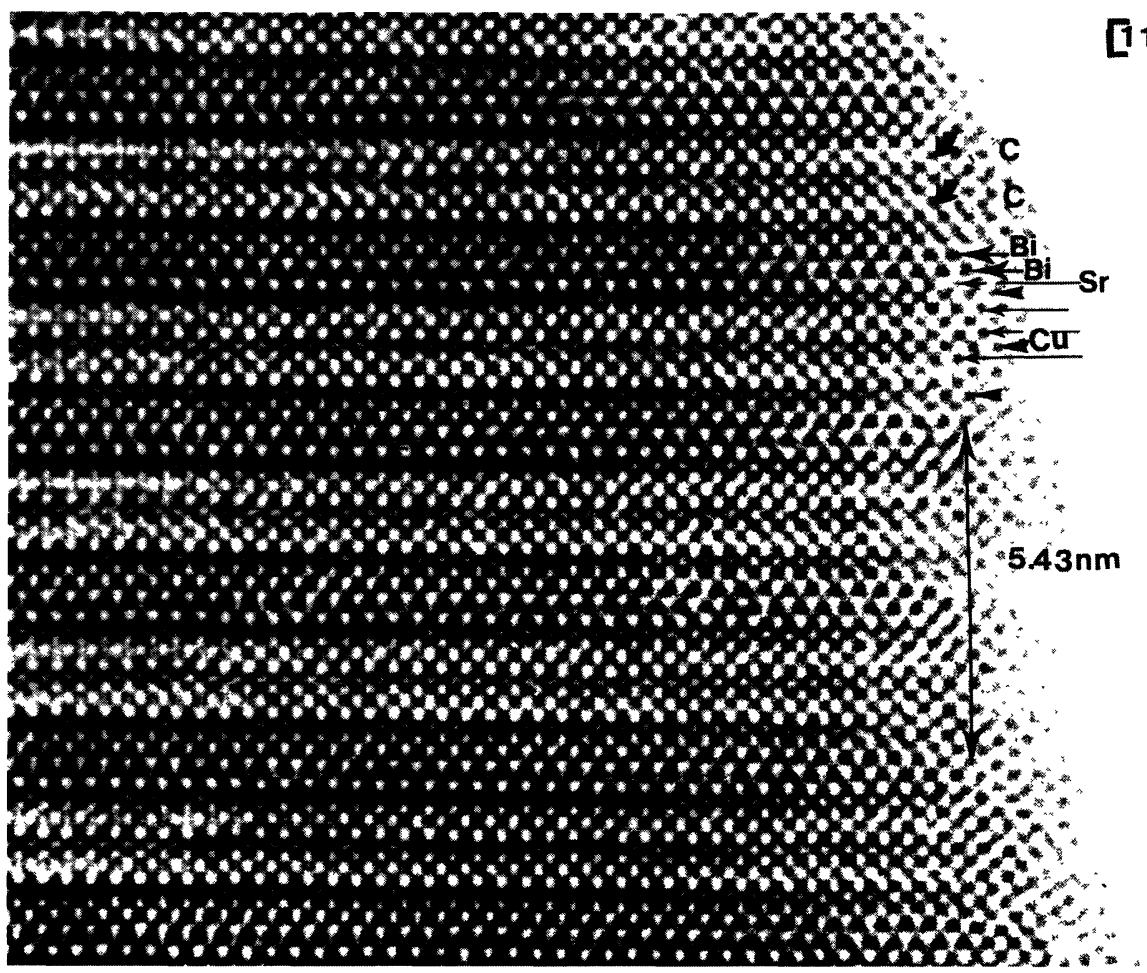

a)
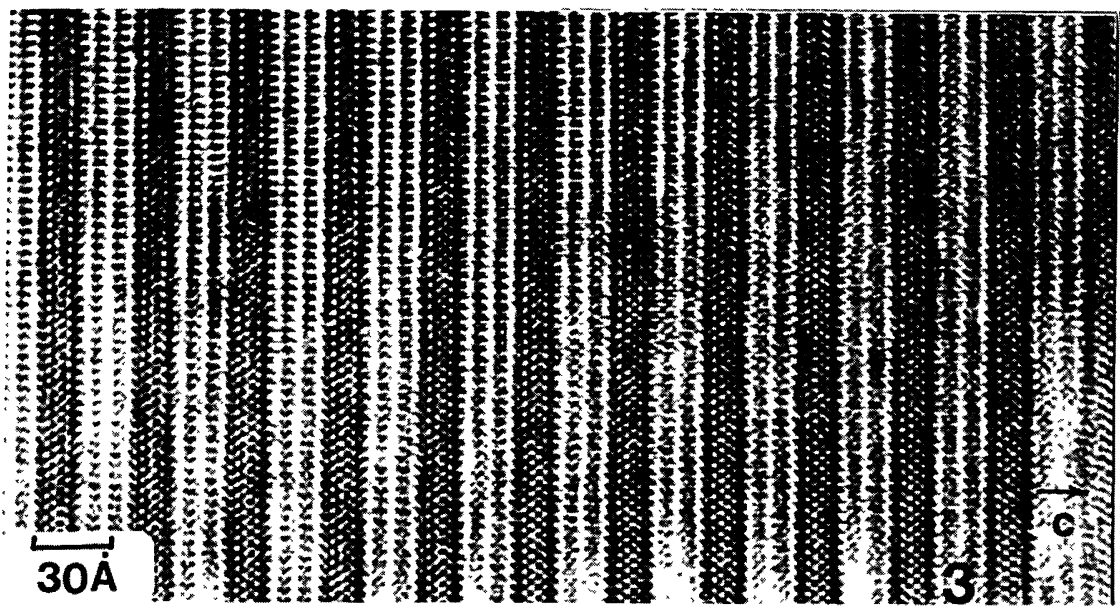

b)

Fig. 9. - HREM images of a) a $[2201]_{1}\left[\mathrm{Sr}_{2} \mathrm{CuO}_{2} \mathrm{CO}_{3}\right]_{2}$ and b) a $[2201]_{1}\left[\mathrm{Sr}_{2} \mathrm{CuO}_{2} \mathrm{CO}_{3}\right]_{3}$ members of the bismuth oxycarbonate family. The carbonate rows are indicated by curved arrows in the first image and the double bismuth layer appears as a double row of dark dots, for a periodicity of $5.43 \mathrm{~nm}$ along c. In the second image, the existence of triple adjacent rows of carbonate groups (spaced by $0.75 \mathrm{~nm}$ since separated by copper rows) is clearly visible. 


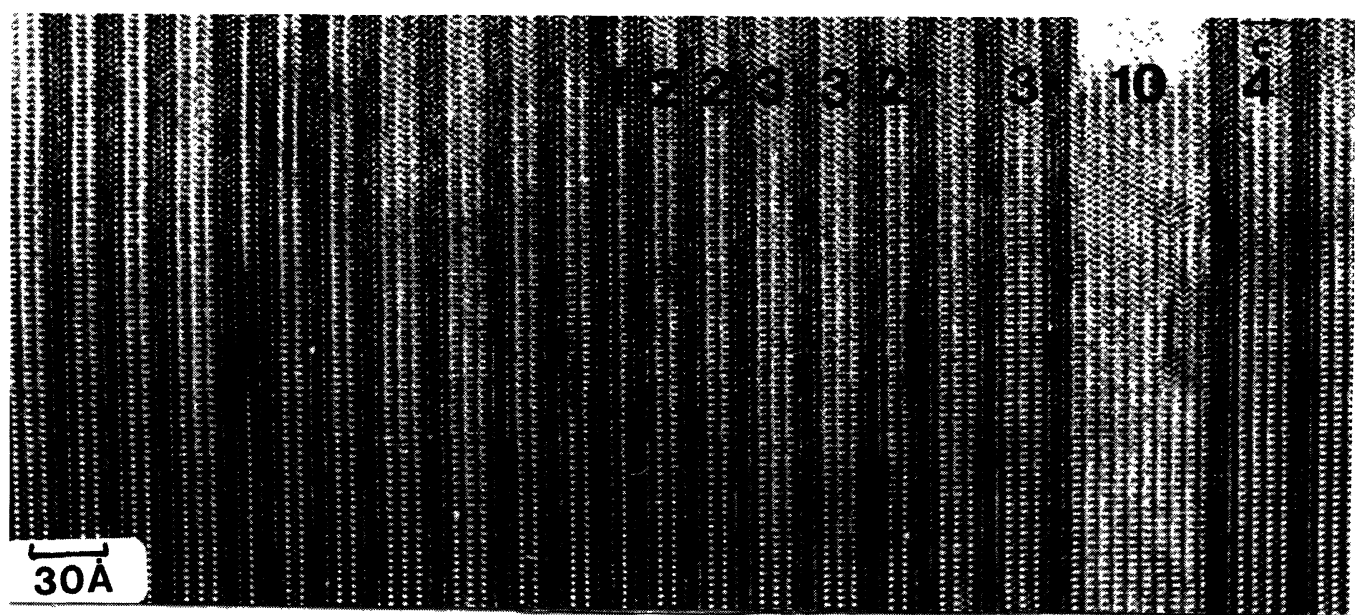

a)

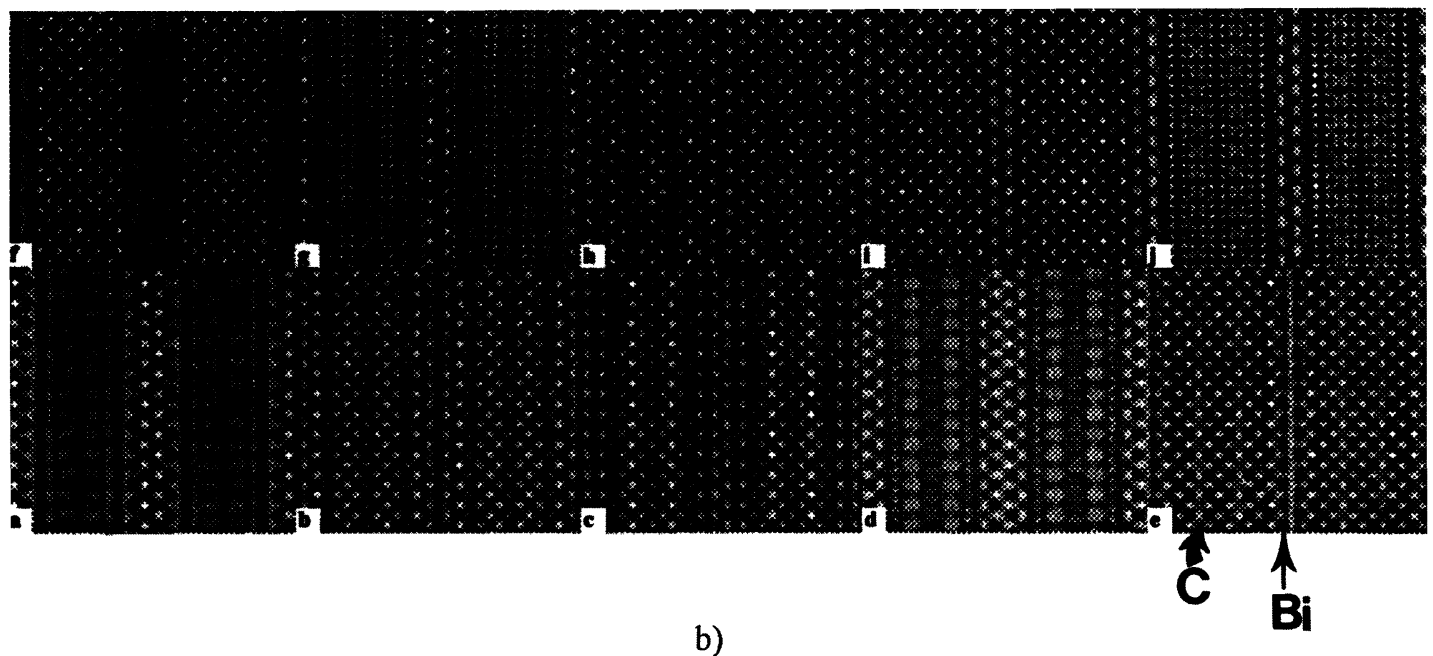

Fig. 10. - a) HREM image showing the existence of $\left[\mathrm{Sr}_{2} \mathrm{CuO}_{2} \mathrm{CO}_{3}\right]_{m}$ defects with $m$ up to 10 in the $[2201]_{1}\left[\mathrm{Sr}_{2} \mathrm{CuO}_{2} \mathrm{CO}_{3}\right]_{1}$ bismuth oxycarbonate. The number of adjacent carbonate rows, i.e. the $m$ value, is indicated by black numbers. b) Calculated images, for focus values ranging from 20 to $-70 \mathrm{~nm}$, of the $[2201]_{1}\left[\mathrm{Sr}_{2} \mathrm{CuO}_{2} \mathrm{CO}_{3}\right]_{1}$ member ([110] orientation, crystal thickness $=30 \AA$ and $\left.\mathrm{Cs}=0.4 \mathrm{~mm}\right)$.

established on a few hundred angstroms wide (curved arrows) and separated by oxycarbonate slices where the phenomenon is not established (straight arrows). In the mixed layer, one cation out of three appears as a brighter dot. The EDS analysis of such a small area shows an increase of the strontium content correlated to a decrease of the $(\mathrm{Hg}+\mathrm{Bi})$ content whereas the $\mathrm{Cu}$ amount remains unchanged: $\mathrm{Hg} / \mathrm{Bi} / \mathrm{Sr} / \mathrm{Cu}=0.3 / 0.4 / 4.3 / 2$. They suggest a local substitution of strontium for mercury and bismuth, according to the formulation $\left[(\mathrm{Bi}, \mathrm{Hg})_{2 / 3} \mathrm{Sr}_{1 / 3}\right] \mathrm{Sr}_{4} \mathrm{Cu}_{2}\left(\mathrm{CO}_{3}\right) \mathrm{O}_{7-\delta}$. Such a composition of the rock salt layers can be compared to that observed in the ordered "1201" cuprate [50]. From these observations a structural model can be proposed (Fig. 12b) with mixed $\left[(\mathrm{Bi}, \mathrm{Hg})_{2 / 3} \mathrm{Sr}_{1 / 3} \mathrm{O}_{\delta}\right]_{\infty}$ layers where the rows of cations running along $\mathbf{b}$ are characterized by the 


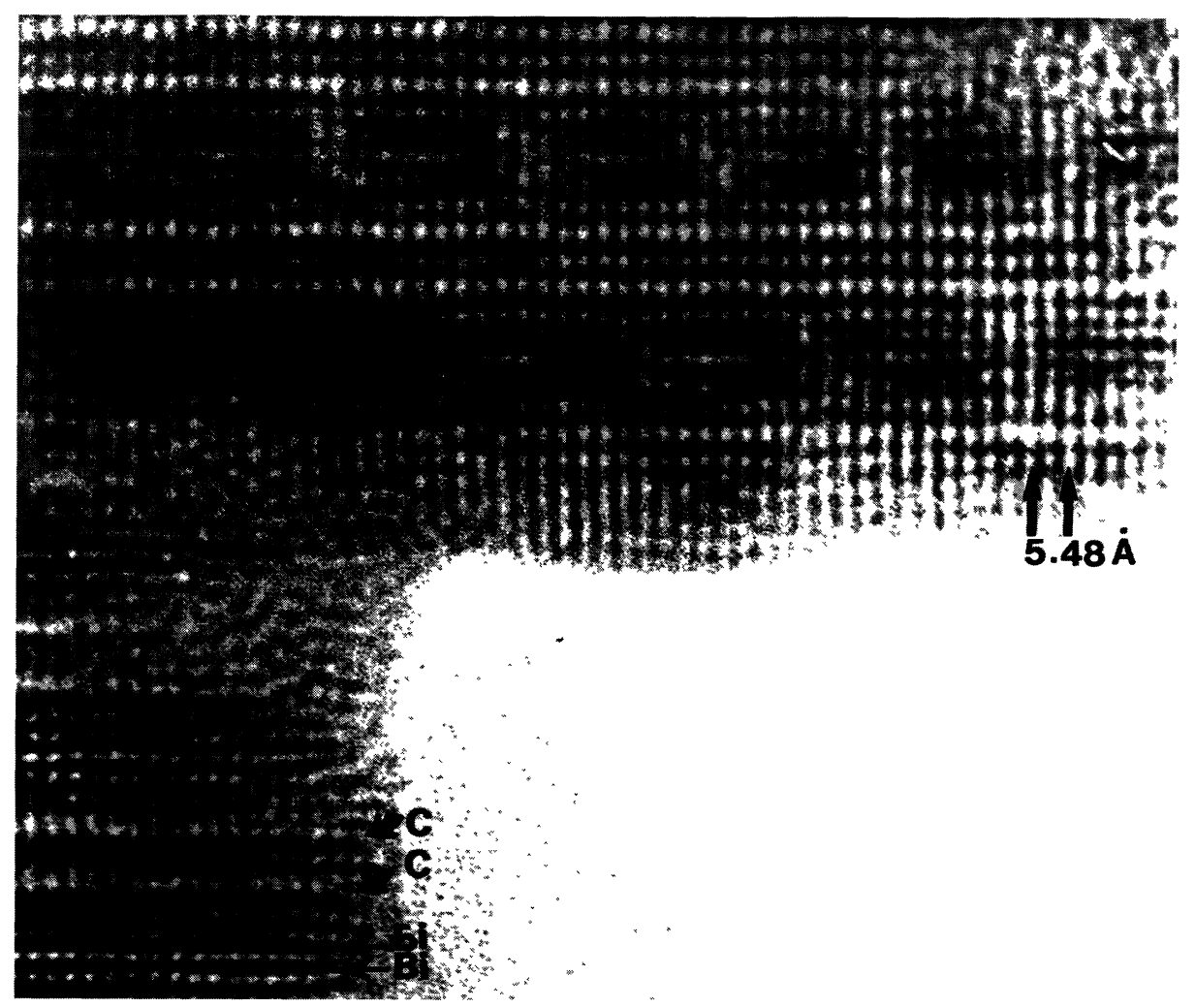

Fig. 11. - $-[100]$ image showing the modulated structure of the $[2201]_{1}\left[\mathrm{Sr}_{2} \mathrm{CuO}_{2} \mathrm{CO}_{3}\right]_{2}$ bismuth oxycarbonate.

ordered sequence " $\mathrm{Sr}-\mathrm{Bi}(\mathrm{Hg})-\mathrm{Bi}(\mathrm{Hg})$ ". The calculated images for the orthorhombic cell " $a_{\mathrm{p}} \times$ $3 a_{\mathrm{p}}$ " confirm this model.

2.2.2 Shearing Mechanisms. - Most of the $\mathrm{Hg}_{0.5} \mathrm{Bi}_{0.5} \mathrm{Sr}_{4} \mathrm{Cu}_{2} \mathrm{O}_{7} \mathrm{CO}_{3}$ crystals show straight boundaries parallel to (010). The mean distance between these boundaries is about $500 \AA$. The enlarged images (Fig. 13a) show that it simply corresponds to a shearing mechanism involving a translation by $c / 2$ of a part of the structure with respect to the other. Through such a mechanism, the mixed $(\mathrm{Hg}, \mathrm{Bi}, \mathrm{Sr}$ ) layers are connected to the carbonate layers and vice-versa (Fig. 13b).

2.3 The Collapsed $[1201]_{m}\left[\mathrm{~S}_{2} \mathrm{CC}\right]_{n}$ oxycarbonates. - A group of new materials is directly related to the $[1201]_{m}\left[\mathrm{Sr}_{2} \mathrm{CuO}_{2} \mathrm{CO}_{3}\right]_{n}$ family. They are generated by a periodic shearing mechanism similar to the one presented as defect for the $\mathrm{Bi} / \mathrm{Hg}$ strontium oxycarbonate (Fig. 13b).

They were firstly observed for a barium for strontium partial substitution in the different $[1201]_{m}$ $\left[\mathrm{Sr}_{2} \mathrm{CuO}_{2} \mathrm{CO}_{3}\right]_{n}$ members. Contrary to the 1201 and 1212 members of the thallium family where solid solutions are obtained, the introduction of barium in the framework of the oxycarbonates $[1201]_{m}\left[\mathrm{~S}_{2} \mathrm{CC}\right]_{n}$ induces shearing.

The first original phase was obtained for the nominal compositions $\mathrm{TlSr}_{4-x} \mathrm{Ba}_{x} \mathrm{Cu}_{2}\left(\mathrm{CO}_{3}\right) \mathrm{O}_{7}$, with $1 \leq x \leq 2$ [51]. The E.D. study gave evidence of an orthorhombic cell with $a=3.85 \AA=a_{\mathrm{p}}$, $b=30.51 \AA \approx 8 a_{\mathrm{p}}$ and $c=16.73 \AA$ and possible space groups Ammm and Amm2. 

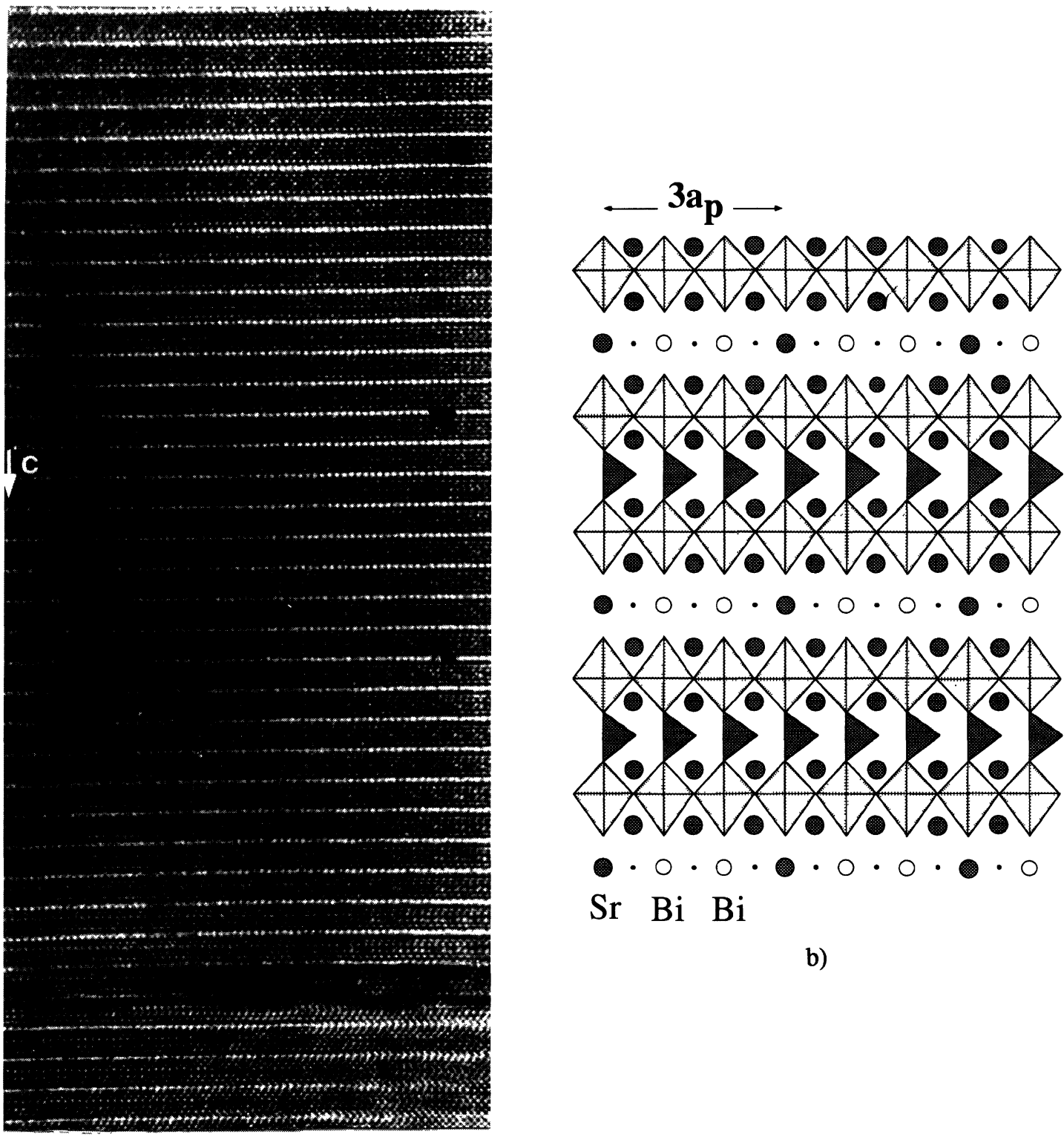

- $0 \cdot 0$.

$\mathrm{Sr} \mathrm{Bi} \mathrm{Bi}$

b)

a)

Fig. 12. - a) Ordering phenomena in mixed $\left[(\mathrm{Bi}, \mathrm{Hg})_{2 / 3} \mathrm{Sr}_{1 / 3} \mathrm{O}_{\delta}\right]$ layers. The non ordered layers are indicated by straight arrows, $\mathbf{b}$ ) idealized model of the ordered structure projected along $\mathbf{a}$.

The way the different cations are distributed in the matrix is understood from HREM images (Fig. 14), so that a structural model was proposed. Starting from the structure of $[1201]\left[\mathrm{Sr}_{2} \mathrm{CuO}_{2}\right.$ $\mathrm{CO}_{3}$ ] (Fig. 7b), the structure of $\mathrm{TlBa}_{2} \mathrm{Sr}_{2} \mathrm{Cu}_{2}\left(\mathrm{CO}_{3}\right) \mathrm{O}_{7}$ can be obtained by a shearing mechanism along $\mathrm{c}$ i.e. by a translation of $\mathrm{c} / 2$ of the latter structure every four $\mathrm{CuO}_{6}$ octahedra as schematized in Figure 15a. From this shearing mechanism, it appears that the $\left[\mathrm{CuO}_{2}\right]_{\infty}$ layers and the $[\mathrm{SrO}]_{\infty}$ layers of each block remain unchanged and form infinite layers parallel to (001). This is not the 

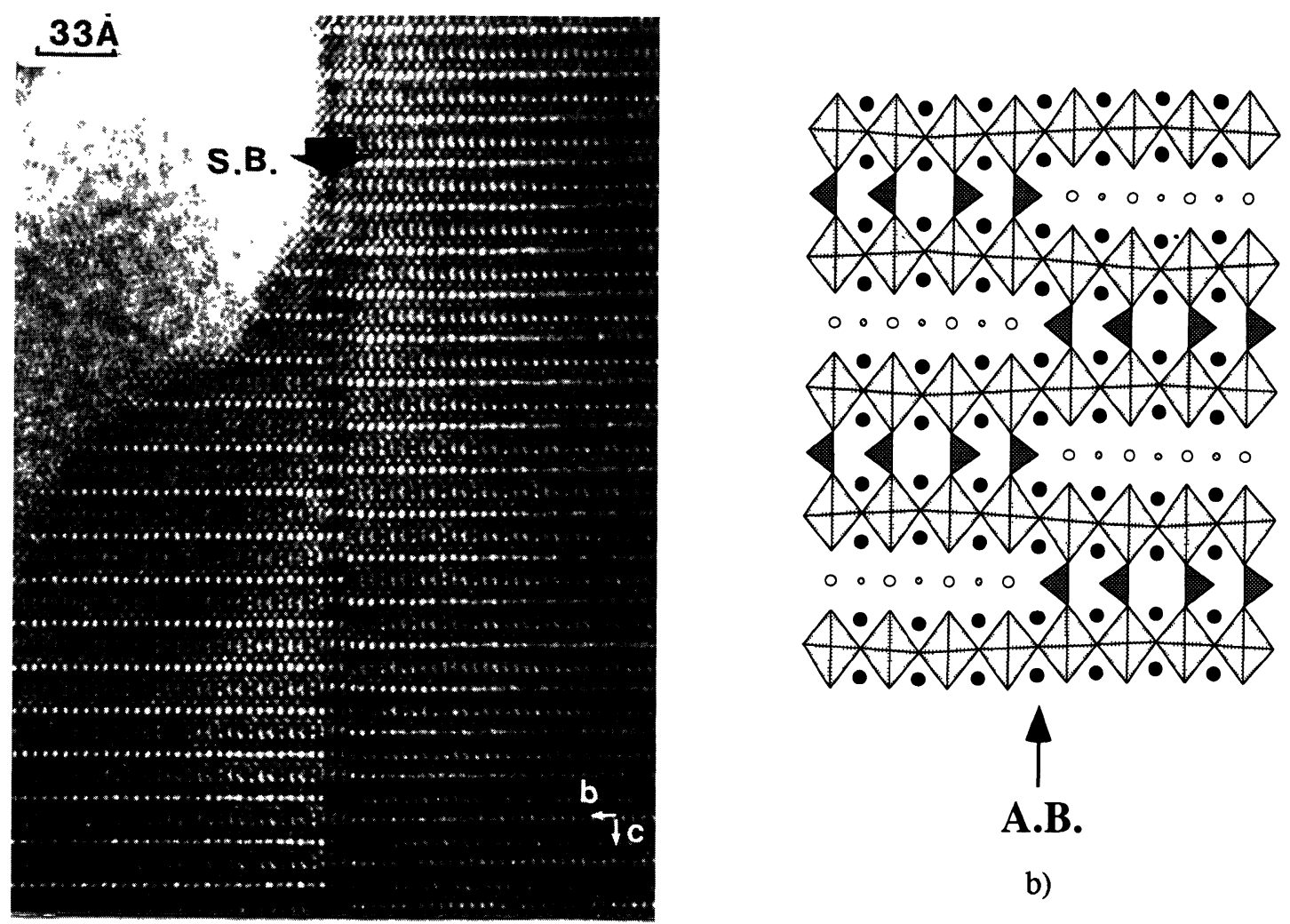

A.B.

b)

a)

Fig. 13. $-\mathrm{Hg}_{0.5} \mathrm{Bi}_{0.5} \mathrm{Sr}_{4} \mathrm{Cu}_{2} \mathrm{O}_{7} \mathrm{CO}_{3}$ : a) formation of shearing mechanism and b) connection of the different layers.

case for the $[\mathrm{TlO}]_{\infty}$ ribbons which are limited to four $\mathrm{Tl}$ atoms along $\mathbf{b}$ and are connected to ribbons of four $\mathrm{CO}_{3}$ groups. Thus, the $[\mathrm{AO}]_{\infty}$ and $[\mathrm{CO}]_{\infty}$ layers of the $[1201]\left[\mathrm{Sr}_{2} \mathrm{CuO}_{2} \mathrm{CO}_{3}\right]$ structure (with $\mathrm{A}=\mathrm{Tl}, \mathrm{Bi}, \mathrm{Pb}, \mathrm{Hg}$ ) are replaced by mixed layers $\left[(\mathrm{TlO})_{4}(\mathrm{CO})_{4}\right]_{\infty}$ characterized by a sequence of four thallium atoms and four carbonate groups along $\mathbf{b}$.

Such a replacement of thallium by carbon within a same layer rises the issue of the adaptation of these elements owing to their large size differences which imply Tl-O apical distances of about $2.00 \AA$, much larger than the $\mathrm{C}$-O distances along $\mathrm{c}$ (about $1.30 \AA$ ). The answer to this question was given by the [100] HREM images for different focus values. For the focus values where the atoms of the $\left[\mathrm{CuO}_{2}\right]_{\infty}$ layers are highlighted (Fig. 14c), it can be seen that these layers undulate with a rather large amplitude. The validity of this model was checked by image calculations. The atomic positions of the cations $\mathrm{Tl}, \mathrm{Ba}, \mathrm{Sr}$ and $\mathrm{Cu}$ were deduced from powder $\mathrm{X}$-ray data refinements; since it is unreasonable to refine the atomic positions of carbons and oxygens in a such complex matrix, these atoms were located in ideal positions, taking into consideration the usual interatomic distances. The projection of this structure is shown in Figure 15a. Image calculations have been performed for this model varying the crystal thickness and the focus values. For the Scherzer value $(-20 \mathrm{~nm})$, we observe at the level of the mixed layer (curved arrow) the alternation of four black dots, correlated to $\mathrm{Tl}$ positions, with four grey dots, correlated to the carbon positions; the grey dots are surroundèd by four bright dots, correlated to oxygen and vacancy positions, as explained above. A superimposition of the calculated and experimental images is shown in Figure 14c. 


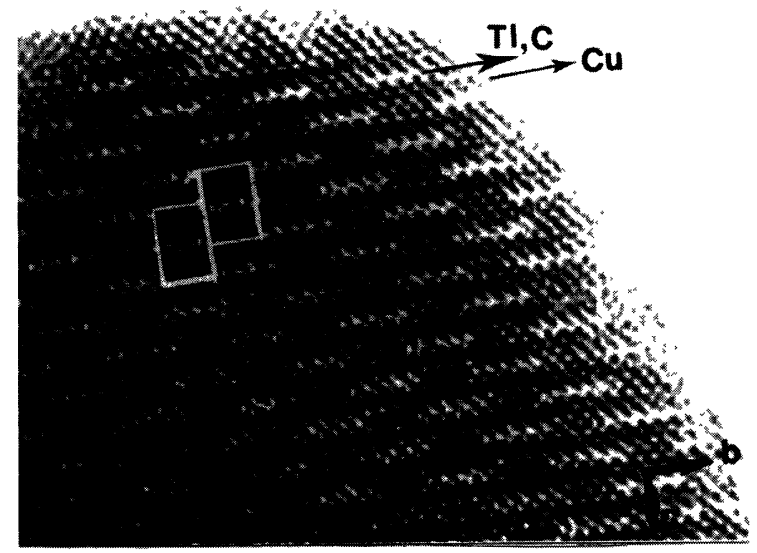

a)

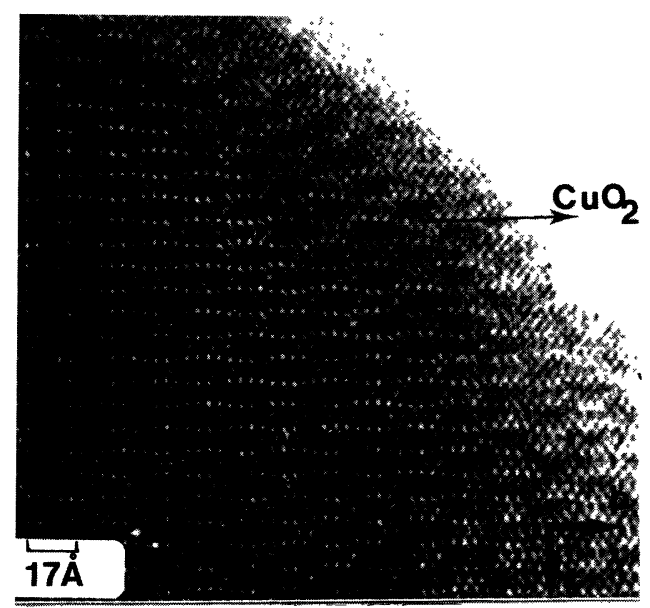

b)

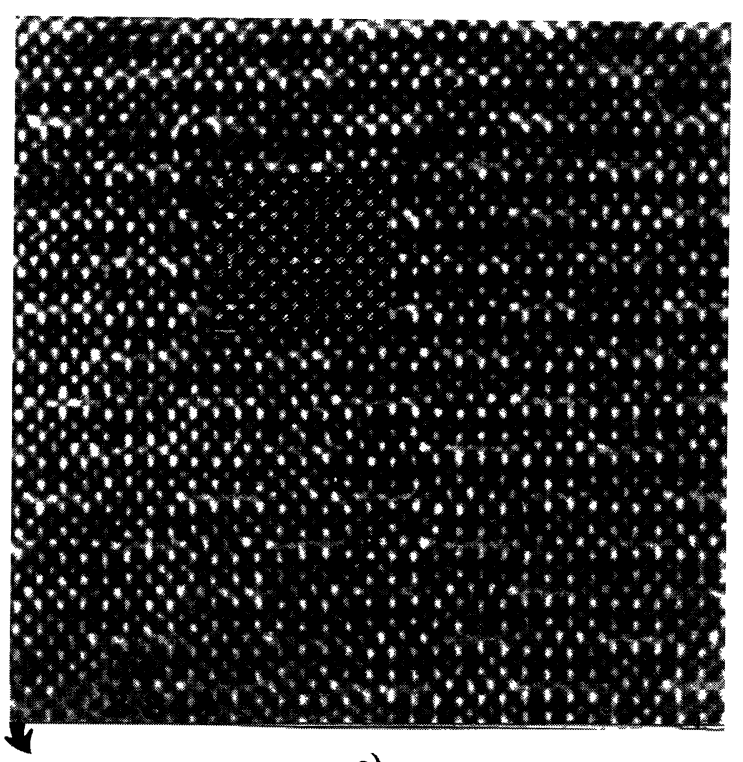

c)

Fig. 14. - $\mathrm{TlBa}_{2} \mathrm{Sr}_{2} \mathrm{Cu}_{2} \mathrm{O}_{7} \mathrm{CO}_{3}$ : a) HREM image of the collapsed structure where the position of the carbonate groups appears as very bright dots, b) HREM image where the $\left[\mathrm{CuO}_{2}\right]$ layers are highlighted showing the strong undulation of the copper layers and c) comparison of the experimental and calculated images for $D f \approx-20 \mathrm{~nm}$.

The structure of this new oxycarbonate (Fig. 15a) therefore consists of modulating single perovskite layers connected through $\left[(\mathrm{TlO})_{4}(\mathrm{CO})_{4}\right]_{\infty}$ layers. Two successive perovskite layers wave in antiphase so that the larger spaces between such layers are occupied by thallium whereas the $\mathrm{CO}_{3}$ groups are located in the narrower spaces.

In fact, this new structure is also closely related to that of the 1201-thallium cuprates $\mathrm{TlBa}_{2} \mathrm{CuO}_{5}$ [52] and $\mathrm{Tl}_{0.5} \mathrm{~Pb}_{0.5} \mathrm{Sr}_{2} \mathrm{CuO}_{5}$ [53] which consists of single perovskite layers intergrown with rock salt layers (Fig. 15b). They can be described as a " 1201 " type structure in which the $[\mathrm{TlO}]_{\infty}$ layers 


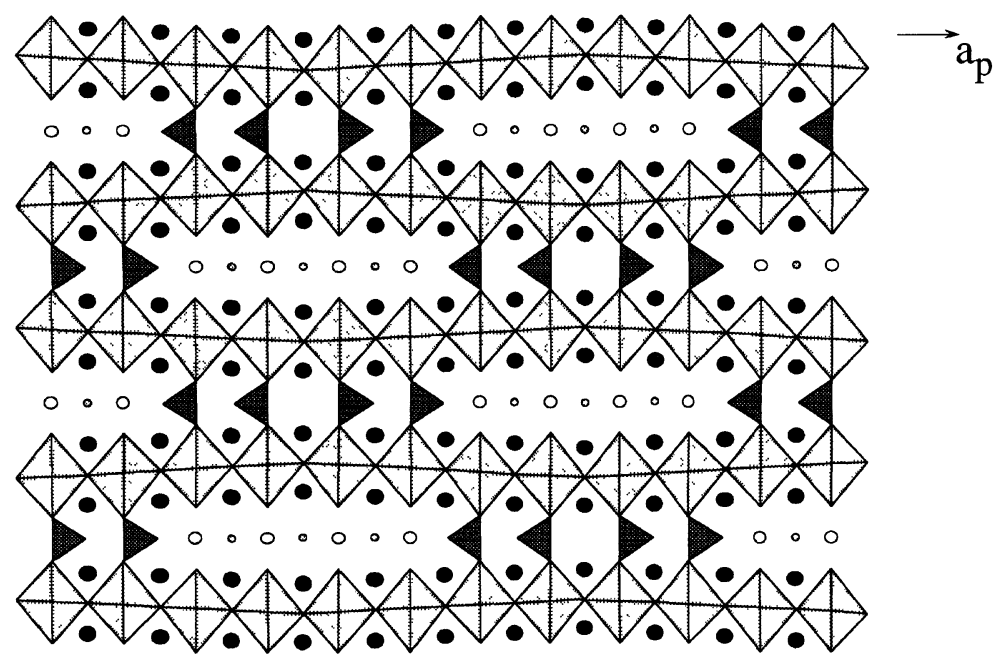

$\{010\}$ collapsed oxycarbonate $\left(1201 / S_{2} C C\right) \quad$ a)

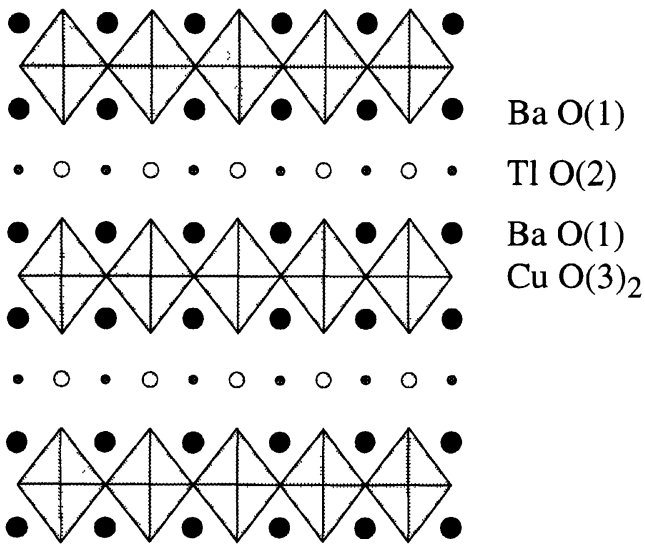

1201

b)

Fig. 15. - Idealized drawings of the a) collapsed oxycarbonate $\mathrm{TlBa}_{2} \mathrm{Sr}_{2} \mathrm{Cu}_{2} \mathrm{O}_{7} \mathrm{CO}_{3}$, b) 1201's showing that the two structures can be described from a single perovskite-type layer intergrown with a double rock salt-type layer. In the collapsed structure the intermediate layer is a mixed $\mathrm{Tl} / \mathrm{C}$ layer whereas in the second one it is a pure $\mathrm{Tl}$ layer.

are replaced by ordered mixed $\left[(\mathrm{TlO})_{4}(\mathrm{CO})_{4}\right]_{\infty}$ layers, involving an undulation of the $\left[\mathrm{SrCuO}_{3}\right]_{\infty}$ perovskite-type layers characterized by a periodicity of eight octahedra.

The ordered presence of carbonate groups and $\mathrm{AO}_{x}$ polyhedra within a single layer involves the formation of modulated structures. In the case of the thallium oxycarbonates, $\mathrm{TISr}_{4-x} \mathrm{Ba}_{x} \mathrm{Cu}_{2}$ $\left(\mathrm{CO}_{3}\right) \mathrm{O}_{7}$, the shear plane is $\{100\}$ but changing the conditions of synthesis and the balance $\mathrm{Ba} / \mathrm{Sr}$ allows to alter the modulation period and obtain commensurate or incommensurate superstructures $[50,54,55]$. 
Different types of modulations have been observed by changing the nature of the cations. In the $\mathrm{Hg}_{0.5} \mathrm{~Pb}_{0.5} \mathrm{Sr}_{3.2} \mathrm{Ba}_{0.8} \mathrm{Cu}_{2}\left(\mathrm{CO}_{3}\right) \mathrm{O}_{7-\delta}$ oxycarbonate [57], the modulation in the (110) plane can be described by a reciprocal vector, $q=m\left(a^{*}+b^{*}\right)$ where $\mathrm{m}$ varies slightly from crystallite to crystallite, but is around $m=0.089$. In real space, this corresponds to a wavelength $\lambda$ of about 11.2 times $d_{110}$.

The XRD and HREM studies show that the mechanism of modulation which results from the $\mathrm{Hg} / \mathrm{C}$ substitution is in fact more complex. It is therefore essential to determine the different parameters which govern the modulations. On the bases of the oxycarbonates synthesized until now, periodic shear planes are only formed in few "pure" strontium oxycarbonates whereas they systematically appear in every "pure" barium based and mixed barium/strontium oxycarbonates. Only one "pure" barium material has indeed been synthesised, $\mathrm{HgBa}_{4} \mathrm{Cu}_{2}\left(\mathrm{CO}_{3}\right) \mathrm{O}_{7-\delta}$ [58], which exhibits a $\{100\}$ modulated structure with a periodicity $q=6 a_{\mathrm{p}}$ along the $\mathbf{b}$ direction. For the mixed $\mathrm{Ba} / \mathrm{Sr}$ oxycarbonates [56,57], the wavelength of the modulation appears as a critical parameter on the orientation of the shear plane; when the structures are $\{100\}$ modulated the $q$ value is 6,7 or 8 (or intermediate non integer values ranging between 6 and 8 ) while the $q$ value ranges between 9 and 11 for the $\{110\}$ modulated structure. The influence of the size of the cation in the $[\mathrm{AO}]$ layer $(\mathrm{A}=\mathrm{Hg}, \mathrm{Tl}, \mathrm{Pb}, \mathrm{Bi}$ or transition metal) which will be ordered along b (collapsed oxycarbonates) or along c (oxycarbonates $1201 / \mathrm{S}_{2} \mathrm{CC}$ ) with the carbonate groups is of importance since the limit compounds $\mathrm{Ba}_{2} \mathrm{CuO}_{2} \mathrm{CO}_{3}$ and $\mathrm{Sr}_{2} \mathrm{CuO}_{2} \mathrm{CO}_{3}$, as well as the solid solution $\mathrm{Ba}_{2-x} \mathrm{Sr}_{x} \mathrm{CuO}_{2} \mathrm{CO}_{3}$, are not modulated.

\section{The Collapsed 2201, 2212 Cuprates and the Collapsed $\left[\mathrm{Bi}_{2} \mathrm{Sr}_{2} \mathrm{CuO}_{6}\right]_{1}\left[\mathrm{Sr}_{2} \mathrm{CuO}_{2} \mathrm{CO}_{3}\right]_{1}$ Oxycarbonate}

As described above, collapsing mechanisms involve that layers of different nature are connected. In the collapsed $[1201]_{m}\left[\mathrm{Sr}_{2} \mathrm{CuO}_{2} \mathrm{CO}_{3}\right]_{n}$ oxycarbonates (Sect. 2), it was shown that the carbonate layers are connected to the $[\mathrm{AO}]$ layers, so that mixed $\left[(\mathrm{A}, \mathrm{C}) \mathrm{O}_{\delta}\right]$ layers are formed but the copper planes remain unchanged in the new structures. The problem is different in the bismuth phases because one additional [BiO] layer exists in the rock salt "slice". This rises the question of the layer interconnection since the rock salt "slice" is built up from the sequence [SrO] [BiO] [BiO] [SrO] which would involve a more complex junction, especially at the level of the copper layers, as that observed in the $[1201]\left[\mathrm{Sr}_{2} \mathrm{CuO}_{2} \mathrm{CO}_{3}\right]$ compounds.

3.1 The Collapsed 2201's And 2212's Bismuth Cuprates. - A large family of original bismuth cuprates where shearing phenomena take place periodically has been characterized: they are termed "the collapsed 2201 and 2212 bismuth cuprates". $\mathrm{Bi}_{17} \mathrm{Sr}_{16} \mathrm{Cu}_{7} \mathrm{O}_{49}$ [59] and $\mathrm{Bi}_{14+x} \mathrm{Sr}_{7} \mathrm{Ba}_{7} \mathrm{Cu}_{7-x} \mathrm{O}_{42+x / 2}$ [60] are the members $n=8$ and $n=7$ of the simple collapsed series $\left(\mathrm{Bi}_{2} \mathrm{~A}_{2} \mathrm{CuO}_{6}\right)_{n-2}\left(\mathrm{Bi}_{4+x} \mathrm{~A}_{4} \mathrm{Cu}_{2-x} \mathrm{O}_{12+x / 2}\right)$. Their structure (Fig. 16b) are derived from that of the superconducting 2201 phase $\mathrm{Bi}_{2} \mathrm{Sr}_{2} \mathrm{CuO}_{6}$ (Fig. 16a) by a periodic shearing along $\mathrm{c}$ forming 2201-type ribbons that are 8 or 7 (Fig. 16b) octahedra wide, respectively. The barium based oxide, $\mathrm{Bi}_{6} \mathrm{Ba}_{4} \mathrm{Cu}_{2} \mathrm{O}_{15}$ [61], can be described as a double collapsed phase; it consists indeed of a first translation along $\mathbf{c}$ similar to that observed in the strontium phase (Fig. 16b), combined with a translation along b of $a_{\mathrm{p}} \sqrt{2}$ (Fig. 16c). The crystallographic collapsing plane (CCP) is $\{010\}_{2201}$ in the two $\mathrm{Sr}$ phases, whereas it is $\{012\}_{2201}$ in the pure $\mathrm{Ba}$ phase. In all these structures a "Bi" string is connected to a " $\mathrm{Sr}(\mathrm{Ba})$ " string on one side and to a " $\mathrm{Cu}$ " string on the other side.

A collapsed 2212 bismuth cuprate, $\mathrm{Bi}_{16} \mathrm{Sr}_{28} \mathrm{Cu}_{17} \mathrm{O}_{69+\delta}$, has also been synthesized for the first time [62]; it crystallises in a monoclinic cell with $a=49.762 \AA, b=5.494 \AA, c=16.433 \AA$ and $\beta=111.32^{\circ}$, with $C_{2 / m}, C_{m}$ and $C_{2}$ as possible space groups. The [010] HREM images (Fig. 17a) 


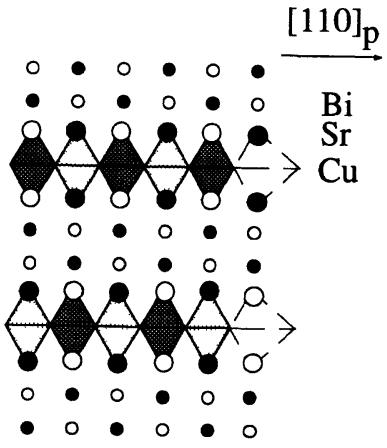

a)

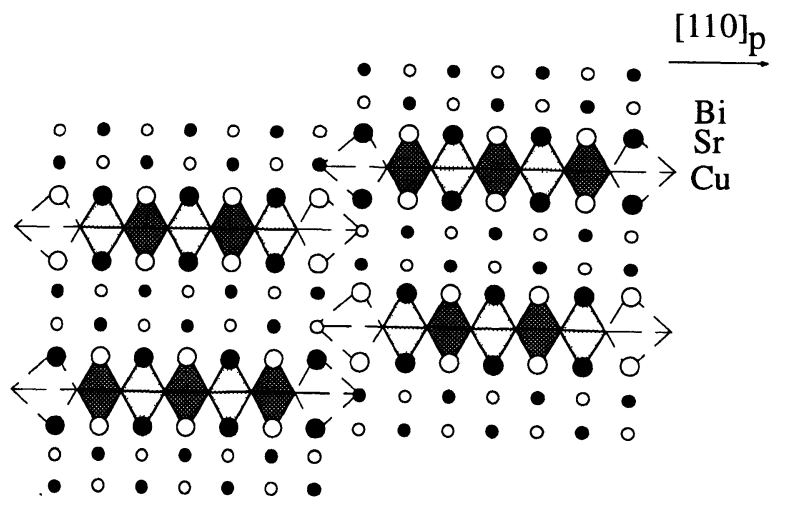

"2201" collapsed : $\mathrm{n}=7$

b)

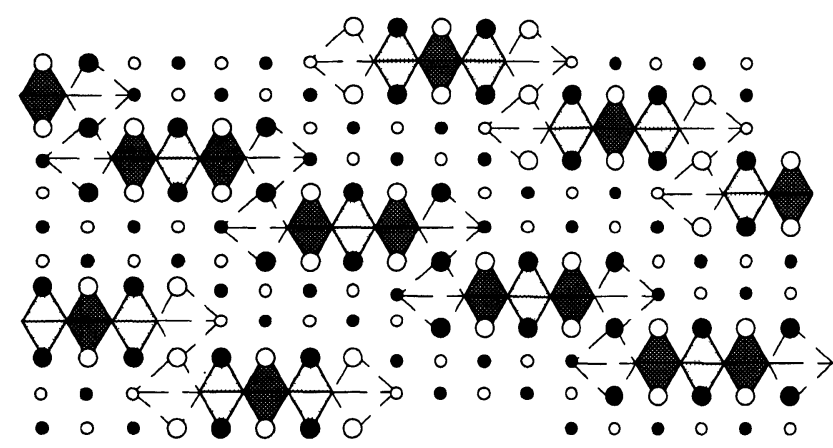

"2201" double collapsed : $\mathbf{n}=5$

c)

Fig. 16. - Idealized structures of a) (2201), b) $n=7-2201$ collapsed and c) double 2201 collapsed phase.

allows the superstructure along a to be interpreted. To understand the mode of layer connection, a theoretical model, based on an undistorted 2212 framework, is shown in Figure $17 \mathrm{~b}$. This structure can be described as a double collapsed 2212, the CCP being $\{011\}_{2212}$; it is a $n=9$ member, refering to the width of the 2212 ribbons. Through the junction, each $(\mathrm{BiO})_{9}$ segment is connected to a $[\mathrm{SrO}]_{26}$ segment on one side and to a $\left[\mathrm{CuO}_{2}\right]_{17}$ segment on the other side; such a linking of the segments is similar to that observed in the 2201 collapsed phases. In the same way, one $\left[\mathrm{CuO}_{2}\right]_{17}$ segment is connected to two $[\mathrm{BiO}]_{9}$ segments and one [SrO $]_{26}$ segment is connected to two $[\mathrm{BiO}]_{9}$ segments. The ideal formula, $\mathrm{Bi}_{18} \mathrm{Sr}_{26} \mathrm{Cu}_{17} \mathrm{O}_{70}$, is close to the nominal composition, $\mathrm{Bi}_{16} / \mathrm{Sr}_{28} / \mathrm{Cu}_{17}$. This idealized model must, in fact, be corrected considering the experimental images. Firstly, the $[\mathrm{BiO}]_{\infty}$ ribbons modulate according to a movement similar to that observed in the 2212 modulated superconductor and the collapsed 2201 phases. The other layers modulate also in the matrix, since they suffer this modulation and because they are connected to another layer which exhibits different thicknesses. Second, at the level of the connection of the different [010] tapes, contrast variations suggest cationic substitutions which would explain the difference between the actual and theoretical compositions. 

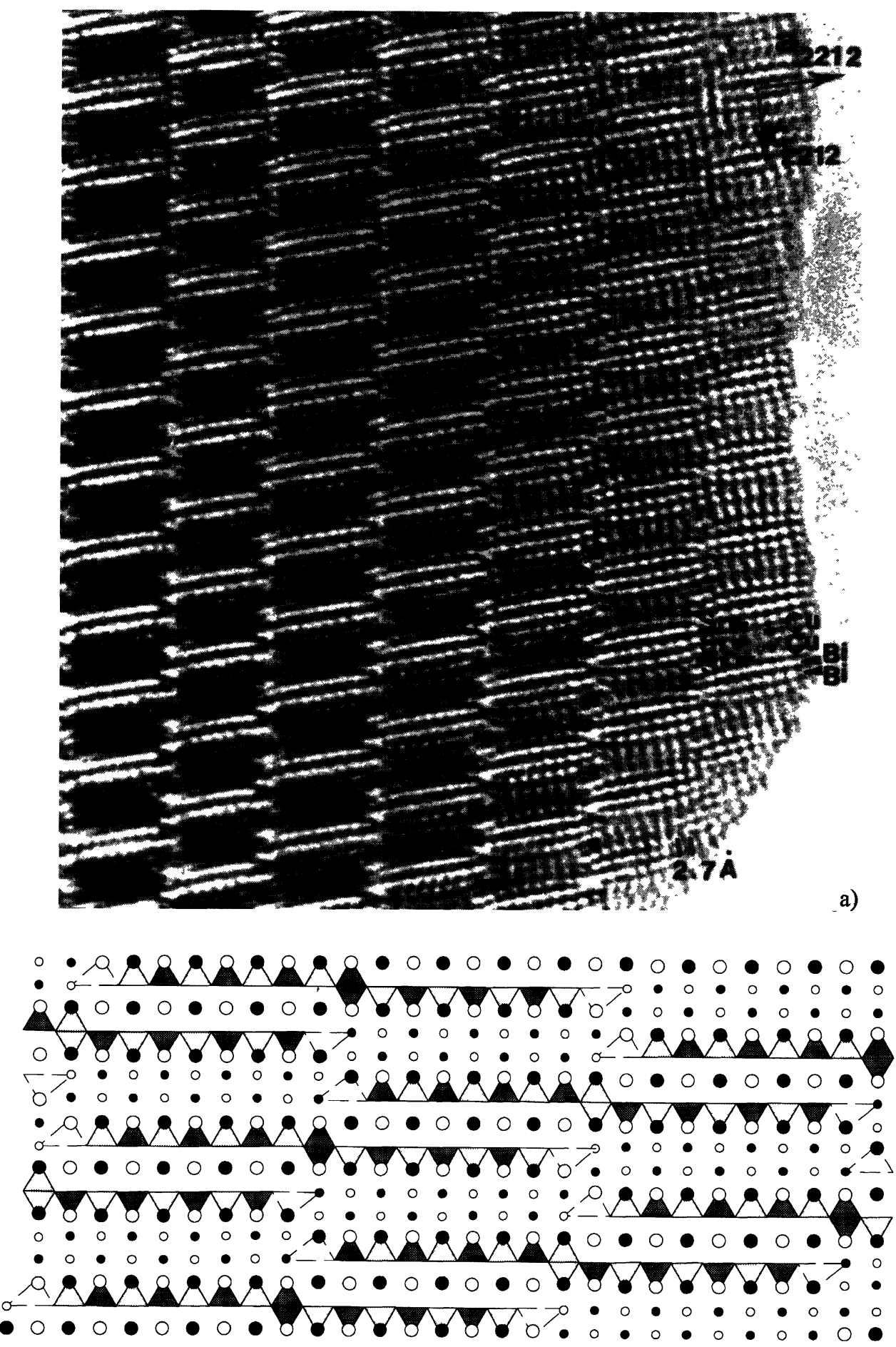

"2212" collapsed : $\mathbf{n}=9$

Fig. 17. - a) [010] HREM image of the double collapsed 2212 phase and b) idealized drawing of the 2212 double collapsed structure. 
The collapsed oxycarbonate, $\mathrm{Bi}_{15} \mathrm{Sr}_{29} \mathrm{Cu}_{12}\left(\mathrm{CO}_{3}\right)_{7} \mathrm{O}_{56}$, exhibits also a monoclinic cell, with $a=$ $18.796 \AA, b=5.486 \AA, c=39.506 \AA$ and $\beta=111.67^{\circ}$, with $A_{2 / m}, A_{m}$ and $A_{2}$ as possible space groups [63]. As for the other bismuth based phases, the cation distribution of this complex structure has been identified using HREM and the previous works on modulated collapsed and oxycarbonate phases. The existence of $\mathrm{Bi}_{2} \mathrm{Sr}_{4} \mathrm{Cu}_{2}\left(\mathrm{CO}_{3}\right) \mathrm{O}_{8}$ - type ribbons running along $\mathrm{c}$ is, here again, straightforward and the identification of the layer sequence within the 7 octahedra wide ribbons is the first step. In Figure 18a, the heavy atom positions appear as bright dots. The contrast can be described from two groups of rows of bright dots: the first one is a group of four rows, oval shaped, correlated to the sequence $(\mathrm{SrO})_{7}-(\mathrm{BiO})_{7}-(\mathrm{BiO})_{7}-(\mathrm{SrO})_{7}$; the second is a group of two rows correlated to two $(\mathrm{SrO})_{7}$ ribbons. The layer sequence along $\mathbf{c}$ within the ribbons is that of the $m=1$ and $n=1$ oxycarbonate $\mathrm{Bi}_{2} \mathrm{Sr}_{4} \mathrm{Cu}_{2}\left(\mathrm{CO}_{3}\right) \mathrm{O}_{8}$ [42]. The formation of ribbons results from a collapsing operation: one CCP is parallel to the (010) plane of the orthorhombic oxycarbonate $\mathrm{Bi}_{2} \mathrm{Sr}_{4} \mathrm{Cu}_{2}\left(\mathrm{CO}_{3}\right) \mathrm{O}_{8}$, i.e to the $(010)_{2201}$ plane since the latter can be described from the intergrowth of 2201 and $\mathrm{Sr}_{2} \mathrm{CuO}_{2} \mathrm{CO}_{3}$ units (Fig. 7c) and exhibits a and $\mathrm{c}$ axes parallel to those of the 2201 structure. Two oval shaped "Bi" segments are translated about $10 \AA$ along c. The connection of the (010) tapes, through the CCP, can be easily observed on the images. An idealized model of the collapsed oxycarbonate is shown in Figure 18b. Such a theoretical structure would correspond to the ideal formula $\mathrm{Bi}_{14} \mathrm{Sr}_{28} \mathrm{Cu}_{14} \mathrm{O}_{56}\left(\mathrm{CO}_{3}\right)_{7}$; however, as mentioned for the 2212 collapsed cuprate, the contrast variation at the level of the CCP plane suggests the existence of local cationic substitution, such as the replacement of copper by $\mathrm{Bi}$ or $\mathrm{Sr}$ atoms at the extremities of the copper segments. This is in agreement with the nominal and actual composition which corresponds to the cationic ratio $\mathrm{Bi}_{15} / \mathrm{Sr}_{29} / \mathrm{Cu}_{12}$ instead of $\mathrm{Bi}_{14} / \mathrm{Sr}_{28} / \mathrm{Cu}_{14}$.

This structure can thus be described as a $\{010\}_{2201}$ collapsed oxycarbonate which results from a shearing operation, every seven octahedra, in the $m=1$ and $n=1$ member of the Bi oxycarbonate $\left(\mathrm{Bi}_{2} \mathrm{Sr}_{2} \mathrm{CuO}_{6}\right)_{m}\left(\mathrm{Sr}_{2} \mathrm{CuCO}_{3} \mathrm{O}_{2}\right)_{n}$.

\section{Mixed $\mathrm{Cu} / \mathrm{M}$ Layers: the $\mathrm{YCaBa}_{4} \mathrm{Cu}_{5} \mathrm{MO}_{3} \mathrm{O}_{11}$ Superconductor and the Different Members of the Family $\left(\mathrm{Y}_{1-x} \mathrm{Ca}_{x}\right) \mathrm{Ba}_{2 n} \mathrm{Cu}_{3 n-1} \mathrm{MO}_{3} \mathrm{O}_{7 n-3}$ with $\mathrm{M}=\mathrm{C}, \mathbf{N}$}

Substituting $\mathrm{CuO}_{4}$ groups by $\mathrm{CO}_{3}$ groups in the 123 framework [64-67] leads, most of the time, to a destruction of the superconducting properties of the barium based materials but it is also one of the ways for stabilizing pure " 123 " strontium based materials which cannot be isolated in a $\mathrm{CO}_{2}$ free atmosphere. During the synthesis of 123 ceramics, such unintentional $C$ for Cu substitution mechanisms often occurs, which must however be taken into consideration for optimizing superconducting behaviour.

In the " 123 " structure the $\mathrm{Cu}(1)$ atoms of the square planar groups between the pyramidal layers can partly be replaced by $\mathrm{CO}_{3}$ groups. A systematic exploration of these "123" oxycarbonates was performed. It allows new oxycarbonates $\mathrm{Y}_{1.6} \mathrm{Ca}_{0.4} \mathrm{Ba}_{4} \mathrm{Cu}_{5}\left(\mathrm{CO}_{3}\right) \mathrm{O}_{11}$ and $\mathrm{Y}_{4} \mathrm{Sr}_{8} \mathrm{Cu}_{11}\left(\mathrm{CO}_{3}\right) \mathrm{O}_{25}$ to be isolated which exhibit supercells with $a=2 a_{123}, b=a_{123}, c=2 c_{123}$ (Fig. 19c) and $a=4 a_{123}$, $b=a_{123}, c=c_{123}$, respectively. The HREM studies show that these structures can be described by the ordered replacement of rows of square planar groups by rows of $\mathrm{CO}_{3}$ groups without changing the total oxygen content in the " 123 " structure. The key of the stabilization of such ordered structures deals with the fact that one corner of the triangular $\mathrm{CO}_{3}$ groups is directed toward the adjacent $\mathrm{CuO}_{4}$ square plane at the level of $\mathrm{Cu}(1)$, forming $\mathrm{CuO}_{5}$ pyramids instead of $\mathrm{CuO}_{4}$ groups (Fig. 19a). As a result a large family of oxycarbonates, with the generic formula $(\mathrm{Y}, \mathrm{Ca})_{n}(\mathrm{Ba}, \mathrm{Sr})_{2 n} \mathrm{Cu}_{3 n-1}\left(\mathrm{CO}_{3}\right) \mathrm{O}_{7 n-3}$ can be predicted which correspond to various ordered replacements of $\mathrm{CuO}_{4}$ groups by $\mathrm{CO}_{3}$ groups. The oxycarbonate $\mathrm{Y}_{1.6} \mathrm{Ca}_{0.4} \mathrm{Ba}_{4} \mathrm{Cu}_{5}\left(\mathrm{CO}_{3}\right) \mathrm{O}_{11}$ represents the member $n=2$ of this series and the oxycarbonate $\mathrm{Y}_{4} \mathrm{Sr}_{8} \mathrm{Cu}_{11}\left(\mathrm{CO}_{3}\right) \mathrm{O}_{25}$, the member $n=4$. 


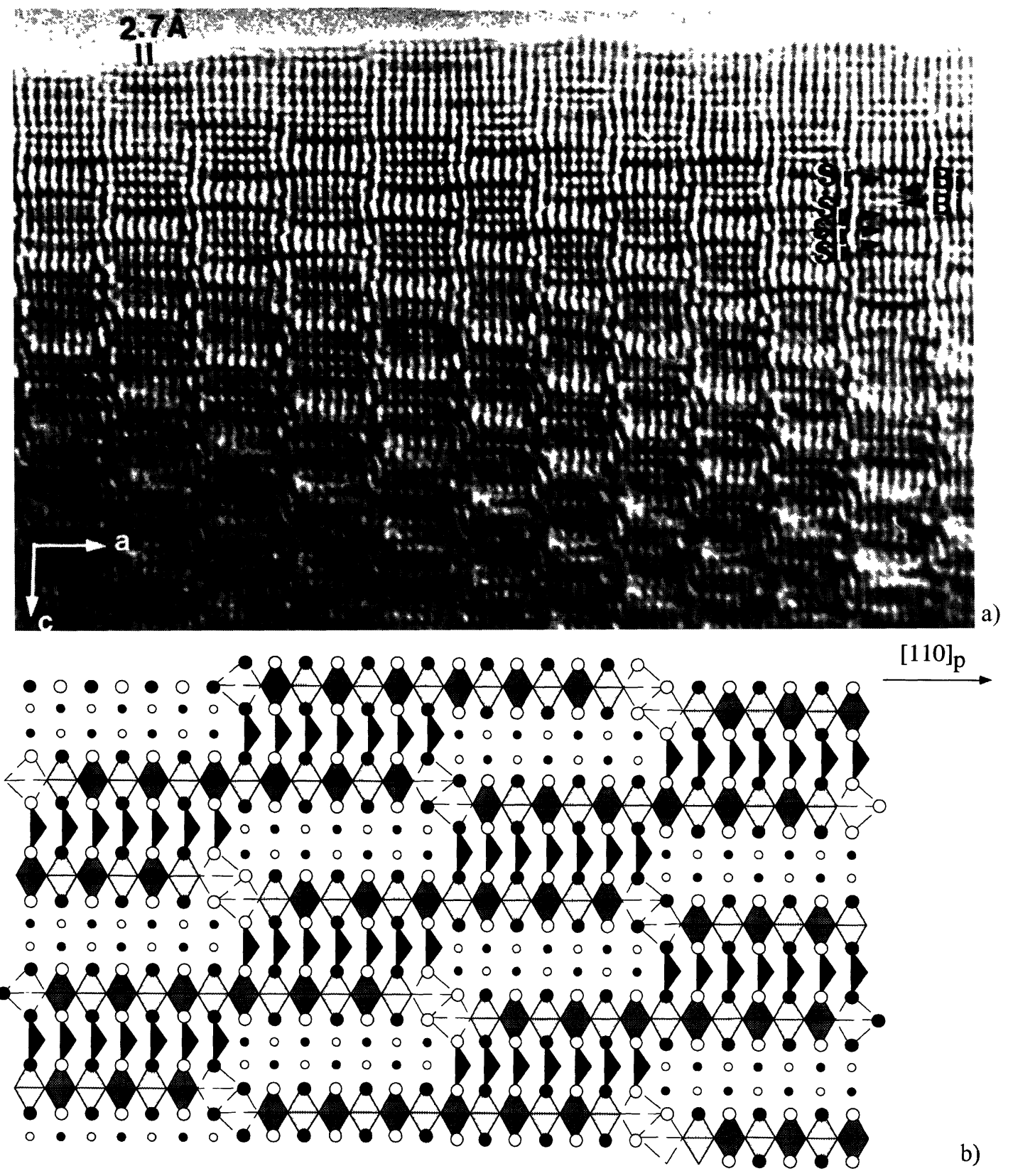

Fig. 18. - a) HREM image of $\mathrm{Bi}_{15} \mathrm{Sr}_{29} \mathrm{Cu}_{12}\left(\mathrm{CO}_{3}\right)_{7} \mathrm{O}_{56}$, b) idealized model of the collapsed oxycarbonate.

The great similarity of the geometry and dimensions of the triangular $\mathrm{NO}_{3}$ groups with the $\mathrm{CO}_{3}$ groups suggests that it should be possible to replace $\mathrm{CO}_{3}$ groups by $\mathrm{NO}_{3}$ according to a mechanism similar to that observed for the carbonates. The oxydizing character of nitrates should be more favorable for the appearance of superconductivity.

The introduction of nitrate groups in the " 123 " matrix [68] leads to a $82 \mathrm{~K}$ new superconductor $\mathrm{YCaBa}_{4} \mathrm{Cu}_{5}\left(\mathrm{NO}_{3}\right)_{0.3}\left(\mathrm{CO}_{3}\right)_{0.7} \mathrm{O}_{11}$ which can be considered as the second member of a large 


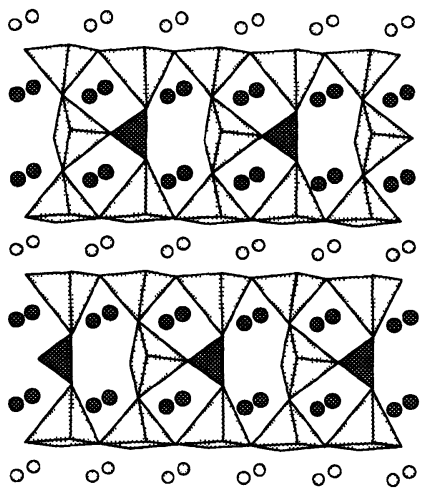

$$
\mathbf{n}=\mathbf{2}
$$
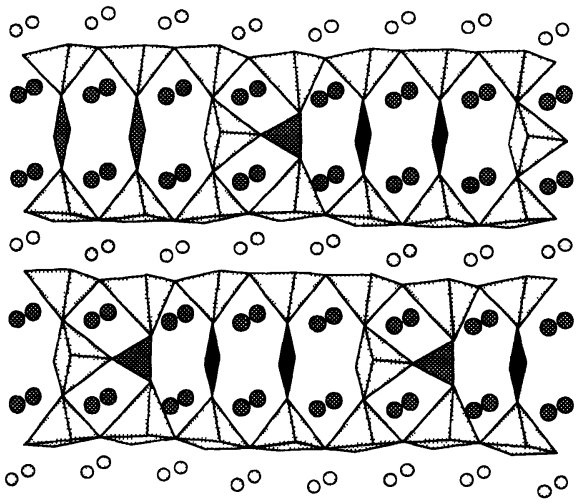

$\mathbf{n}=\mathbf{4}$

a)

\section{$5 \mathrm{~nm}$}

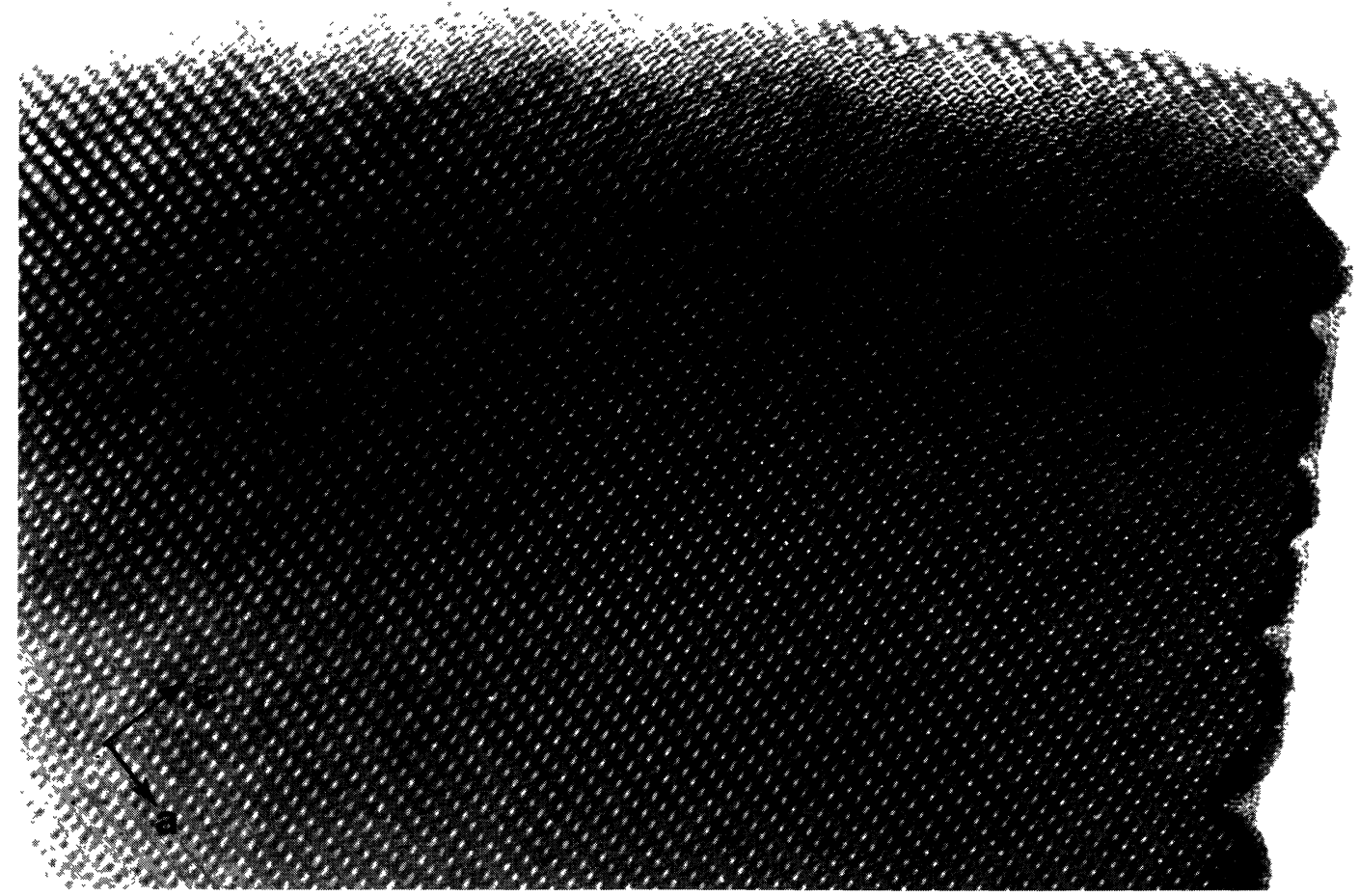

b)

Fig. 19. - a) Idealized models of the $n=2$ and $n=4$ members of the 123-type oxycarbonate, b) overall [010] image showing the regular distribution of the $\mathrm{CO}_{3}$ and $\mathrm{NO}_{3}$ groups in the matrix and c) corresponding ED pattern. 


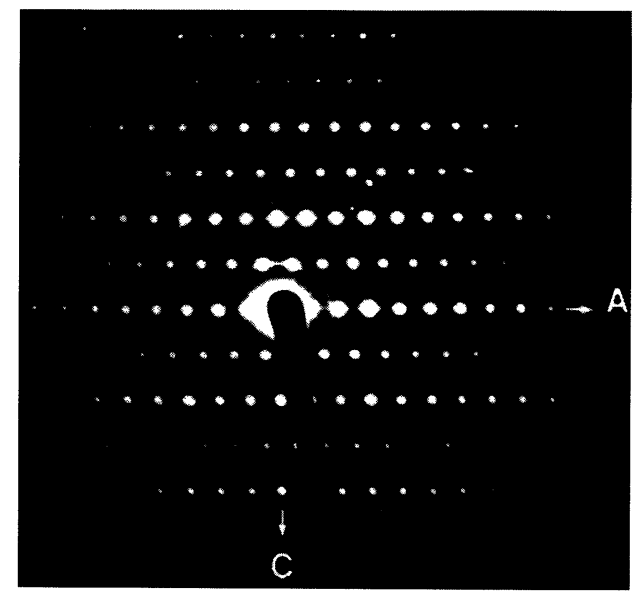

c)

Fig. 19. - (continued)

family $\left(\mathrm{Y}_{1-x} \mathrm{Ca}_{x}\right)_{n} \mathrm{~A}_{2 n} \mathrm{Cu}_{3 n-1}\left(\mathrm{MO}_{3}\right) \mathrm{O}_{7 n-3}[69]$ where $\mathrm{A}$ is $\mathrm{Ba}$ or $\mathrm{Sr}$ and $\mathrm{M}$ is $\mathrm{C}, \mathrm{N}$ or $\mathrm{B}$. The $\mathrm{X}$-ray diffraction patterns of these phases are closely related to that of the "123" structure and can be indexed in a "123" orthorhombic subcell. A typical contrast of the HREM images consists of rows of small white dots, lined up along a (Fig. 19b) with a periodicity of $7.7 \AA$ corresponding to $a \approx 2 a_{123}$; these rows are spaced by $11.5 \AA\left(c_{123}\right)$ but the white dots are shifted by $\mathbf{a}_{123}$ in one row with regard to the adjacent ones so that $c=2 c_{123}$. This contrast is typical of the structure of the 123-type oxycarbonate $\mathrm{Y}_{1.2} \mathrm{Ca}_{0.8} \mathrm{Ba}_{4} \mathrm{Cu}_{5}\left(\mathrm{CO}_{3}\right) \mathrm{O}_{11}$ and is consistent with the ordered substitution of one row of square planar groups out of two in the 123 structure by one row of triangular $\mathrm{CO}_{3}$ and $\mathrm{NO}_{3}$ groups (Fig. 19a) [64,67]. The white dots are correlated to the rows of $\mathrm{CO}_{3}$ or $\mathrm{NO}_{3}$ groups at the level of $\mathrm{Cu}(1)$ in the intermediate layer of the 123 structure. Such images confirm that the substitution is ensured in an almost regular way throughout the crystals. No distinction can be made between nitrate and carbonate groups, in agreement with the almost equal scattering factors of $\mathrm{N}$ and $\mathrm{C}$ and the identical geometry and size of the $\mathrm{NO}_{3}$ and $\mathrm{CO}_{3}$ groups. Under these conditions, the contrast was interpreted using the simulated images calculated for the oxycarbonate $\left(\mathrm{Y}_{1-x} \mathrm{Ca}_{x}\right)_{2} \mathrm{Ba}_{4} \mathrm{Cu}_{5}\left(\mathrm{CO}_{3}\right) \mathrm{O}_{11}$.

The formation of $90^{\circ}$ oriented domains whose size varies in a large range is a frequent feature in these mixed materials. An example is shown in Figure 20a where the two domains and the boundaries are parallel to (001) which is the common plane. In this image, recorded for a focus value close to $-60 \mathrm{~nm}$, the contrast consists of two groups of staggered rows of white dots; the three rows of small dots are correlated to the positions of the $(\mathrm{Y}, \mathrm{Ca})$ and $\mathrm{Cu}(2)$ atoms of the pyramidal layers; the two rows of bright dots of the second group are correlated to the barium positions. Carbonate groups are often localized at the domain boundaries. This preferential localization and the decrease of the orthorhombic distortion of the 123 cell are supposed to generate such oriented domains.

The regularity of the stacking of the rows of $\mathrm{MO}_{3}$ groups $(\mathrm{M}=\mathrm{C}, \mathrm{N})$ and $\mathrm{CuO}_{5}$ pyramids is sometimes broken. This phenomenon corresponds to the local formation of other members of the series $\left(\mathrm{Y}_{1-x} \mathrm{Ca}_{x}\right)_{n} \mathrm{Ba}_{2 n} \mathrm{Cu}_{3 n-1}\left(\mathrm{MO}_{3}\right) \mathrm{O}_{7 n-3}$. In Figure 20b, for a focus value close to $10 \mathrm{~nm}$, we observe clearly the rows of white dots correlated to the $\mathrm{NO}_{3}$ and $\mathrm{CO}_{3}$ groups. It can be seen that for a large part of the crystal, the spacing of these dots is of $7.7 \AA$, characteristic of the $n=2$ matrix, 


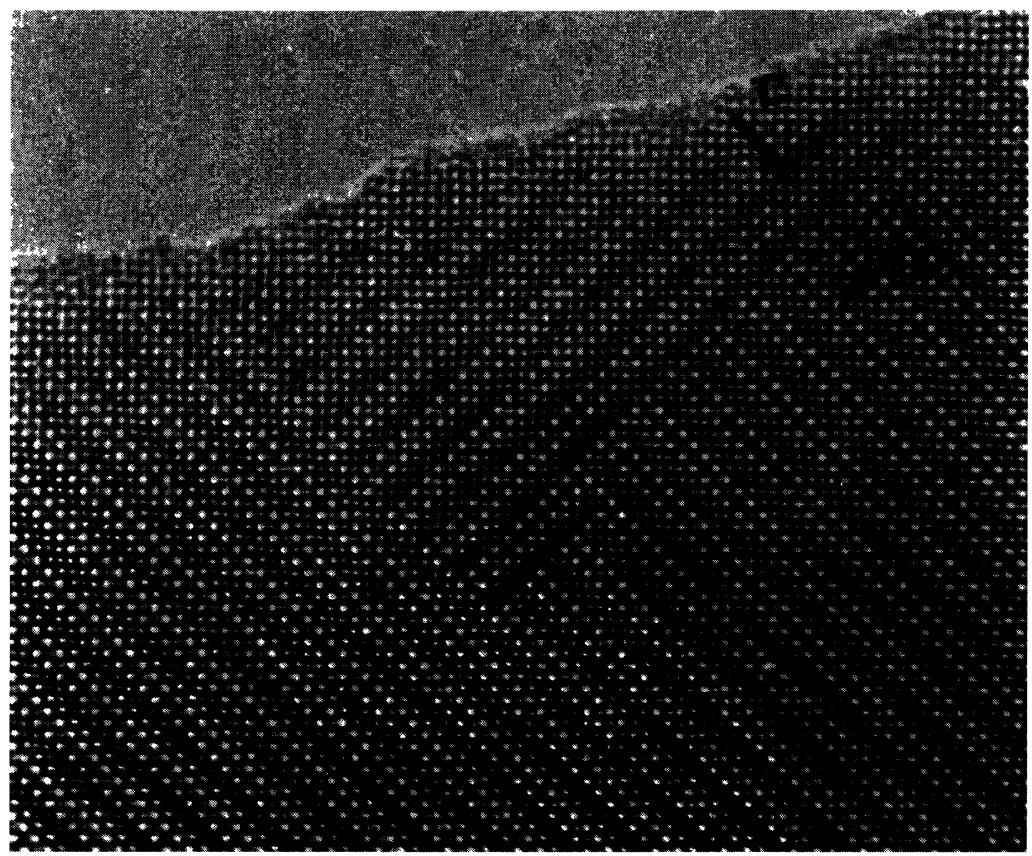

a)

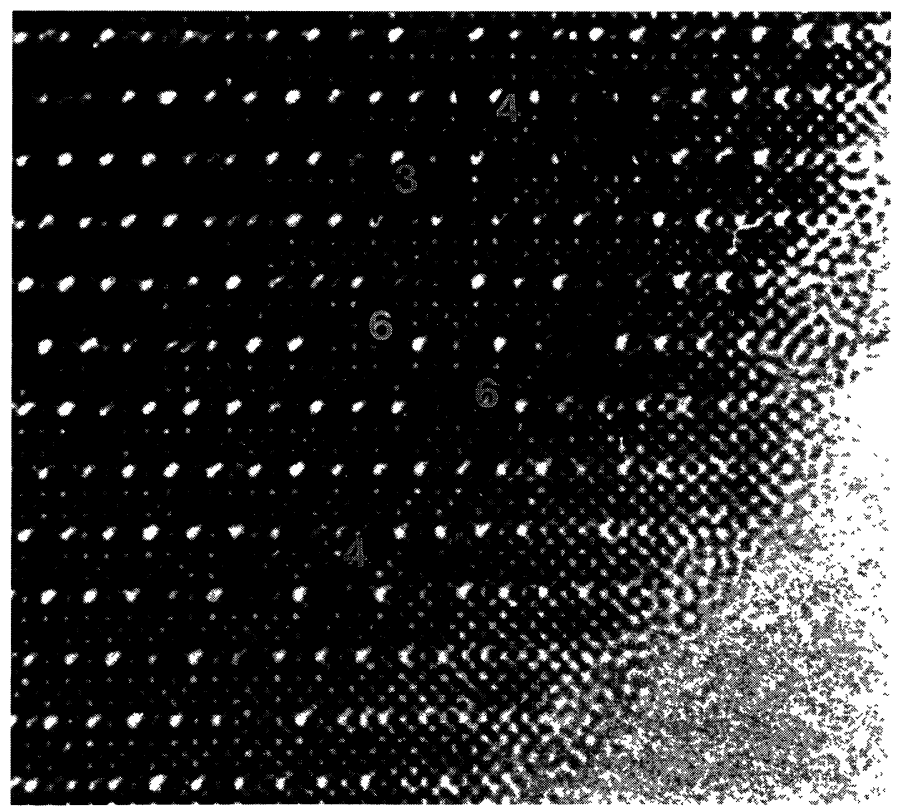

b)

Fig. 20. - a) $90^{\circ}$ oriented domains in the 123 - type oxycarbonitrate and b) aleatory sequences of different $n$ members ( $n$ varying between 2 and 6 ). 
but that this spacing can also take different values, such as $11.55 \AA$, $15.4 \AA, 23.1 \AA$, corresponding to a variation of the superstructure along a, i.e. $a$ equal to $3 a_{123}, 4 a_{123}$ and $6 a_{123}$, respectively. Such defects are easily interpreted as the members $n=3,4$ and 6 of the family; their structure is described as an ordered stacking along a of rows of $\mathrm{CuO}_{5}$ pyramids with rows of $\mathrm{CO}_{3}\left(\mathrm{NO}_{3}\right)$ groups and rows of $\mathrm{CuO}_{4}$ square planar groups according to the sequence " $\mathrm{CuO}_{5}-\mathrm{CO}_{3}-(n-2) \mathrm{CuO}_{4}$ ".

\section{Physical Properties of the Oxycarbonates}

5.1 Oxycarbonates with "Pure" Carbonate Layers. - The very important point which characterizes the physical properties of the oxycarbonates built up from the intergrowth of 1201 or 2201 units with $\mathrm{S}_{2} \mathrm{CC}$ units and forming "pure" carbonate layers (Sect. 2), i.e. the [1201] $]_{m}\left[\mathrm{Sr}_{2}\right.$ $\left.\mathrm{CuO}_{2} \mathrm{CO}_{3}\right]_{n}$ and $[2201]_{m}\left[\mathrm{Sr}_{2} \mathrm{CuO}_{2} \mathrm{CO}_{3}\right]_{n}$ members, is that they exhibit critical temperatures which are higher than those of the 1201, 2201 and $\mathrm{Sr}_{2} \mathrm{CuO}_{2} \mathrm{CO}_{3}$-parent structures. In that way, the $[1201]_{1}\left[\mathrm{Sr}_{2} \mathrm{CuO}_{2} \mathrm{CO}_{3}\right]_{1}$ oxycarbonates with thallium, mercury, $(\mathrm{Tl}, \mathrm{M})$ and $(\mathrm{Hg}, \mathrm{M})(\mathrm{M}=\mathrm{Pb}, \mathrm{Bi}$ and transition elements) layers exhibit critical temperature up to 70-77 $\mathrm{K}$ and good diamagnetic volume fractions, as for example $\mathrm{Tl}_{0.5} \mathrm{~Pb}_{0.5} \mathrm{Sr}_{4} \mathrm{Cu}_{2}\left(\mathrm{CO}_{3}\right) \mathrm{O}_{7}$ whereas the parent oxides $\mathrm{Tl}_{0.5} \mathrm{~Pb}_{0.5} \mathrm{Sr}_{2}$ $\mathrm{CuO}_{5}$ and $\mathrm{Sr}_{2} \mathrm{CuO}_{2} \mathrm{CO}_{3}$ do not superconduct. In the same way, the $[2201]_{1}\left[\mathrm{Sr}_{2} \mathrm{CuO}_{2} \mathrm{CO}_{3}\right]_{n}$ bismuth oxycarbonates with $n=1,2$ and 3 exhibit $T_{\mathrm{c}}$ 's of $30 \mathrm{~K}, 40 \mathrm{~K}$ and $34 \mathrm{~K}$, respectively which are superior to that of the parent structures, $\mathrm{Bi}_{2} \mathrm{Sr}_{2} \mathrm{Cu}_{2} \mathrm{O}_{6}$ which is $22 \mathrm{~K}$ [70] and $\mathrm{Sr}_{2} \mathrm{CuO}_{2} \mathrm{CO}_{3}$ which does not superconduct. Spectacular is also the increase of $T_{\mathrm{c}}$ from $30 \mathrm{~K}$ to $40 \mathrm{~K}$, as the thickness of the non-superconducting layer $\left[\mathrm{Sr}_{2} \mathrm{CuO}_{2} \mathrm{CO}_{3}\right]_{m}$ increases, and which goes through a maximum for $n=2$. It seems that the number of carbonate layers between two successive copper layers plays a role for the optimization of $T_{\mathrm{c}}$. This is to be compared to the behavior of the thallium cuprates $\mathrm{Tl}_{2} \mathrm{Ba}_{2} \mathrm{Ca}_{m-1} \mathrm{Cu}_{m} \mathrm{O}_{2 m+4}$ and $\mathrm{TlBa}_{2} \mathrm{Ca}_{m-1} \mathrm{Cu}_{m} \mathrm{O}_{2 m+3}$ whose $T_{\mathrm{c}}$ increases as the number of copper layers increases and goes through a maximum for $m=3$.

The oxycarbonates which exhibit mixed $\mathrm{C} / \mathrm{A}$ layers (with $\mathrm{A}=\mathrm{Hg}, \mathrm{Tl}, \mathrm{Bi}, \mathrm{Pb}$..) and "pure" carbonate layers (Sect. 2), i.e. the $\{100\}$ and $\{110\}$ collapsed oxycarbonates derived from the $[1201]_{1}\left[\mathrm{Sr}_{2} \mathrm{CuO}_{2} \mathrm{CO}_{3}\right]_{1}$ compounds, exhibit also high critical temperatures, ranging between $60 \mathrm{~K}$ and $70 \mathrm{~K}$, and good diamagnetic volume fractions. It is important to note that, in these collapsed phases, the copper layers remain unchanged through the collapsing mechanism and that the charge balance can be controlled through the cationic composition.

5.2 Oxycarbonates With Mixed CU/C Layers. - In the " 123 "-derivatives $\left(\mathrm{Y}_{1-x} \mathrm{Ca}_{x}\right)_{n}$ $\mathrm{Ba}_{2 n} \mathrm{Cu}_{3 n-1}\left(\mathrm{MO}_{3}\right) \mathrm{O}_{7 n-3}$ with $\mathrm{M}=\mathrm{C}$ or $\mathrm{N}$ (Sect. 4), only two series have been shown to exhibit superconducting properties: $\left(\mathrm{Y}_{1-x} \mathrm{Ca}_{x}\right)_{0.95} \mathrm{Sr}_{2.05} \mathrm{Cu}_{2.4}\left(\mathrm{CO}_{3}\right)_{0.6} \mathrm{O}_{y}$ [71] and $\mathrm{YCaBa}_{4} \mathrm{Cu}_{5}\left(\mathrm{NO}_{3}\right)_{0.3}$ $\left(\mathrm{CO}_{3}\right)_{0.7} \mathrm{O}_{11}$ [68] They both correspond to the $n=2$ members of the above series. These compounds have a $T_{\mathrm{c}}$ (onset) of $66 \mathrm{~K}$ and $82 \mathrm{~K}$ respectively. Generally, the superconducting volume fraction of these material is relatively small and the transitions are broad, suggesting a very inhomogeneous character of the samples. It should be noted that a new family of oxycarbonates exhibiting mixed $\mathrm{Cu} / \mathrm{C}$ layers has been recently obtained at high pressure $[72,73]$ with 1 - 1-type ordering between $\mathrm{Cu}$ and $\mathrm{C}$ along $\mathbf{b}$.

5.3 The Role of the Collapsing Planes. - The cuprate $\mathrm{Bi}_{16} \mathrm{Sr}_{28} \mathrm{Cu}_{17} \mathrm{O}_{69+\delta}$ and the oxycarbonate $\mathrm{Bi}_{15} \mathrm{Sr}_{29} \mathrm{Cu}_{12}\left(\mathrm{CO}_{3}\right)_{7} \mathrm{O}_{56}$, represent two original collapsed structures that are deduced from the layered cuprates and oxycarbonates by applying a shearing mechanism (Sect. 3). The collapsed copper-based phases that have been synthesized up to date are listed in table III, together with their basic structures. Among these compounds, $\mathrm{Bi}_{16} \mathrm{Sr}_{28} \mathrm{Cu}_{17} \mathrm{O}_{69+\delta}$ is the only one that involves $\mathrm{CuO}_{5}$ pyramids, the seven others being built up from $\mathrm{CuO}_{6}$ octahedra. In the same 


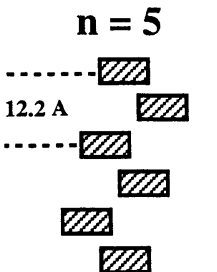

$\mathbb{Z Z}$

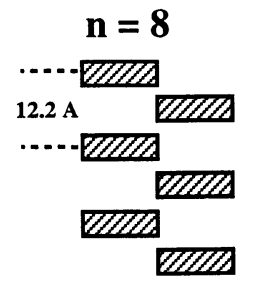

$\mathrm{Bi}_{17} \mathrm{Sr}_{16} \mathrm{Cu}_{8} \mathrm{O}_{49}$

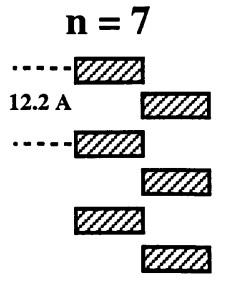

$\mathrm{Bi}_{15 \mathrm{~A}}{ }_{14 \mathrm{Cu}} \mathrm{O}_{42.5}$

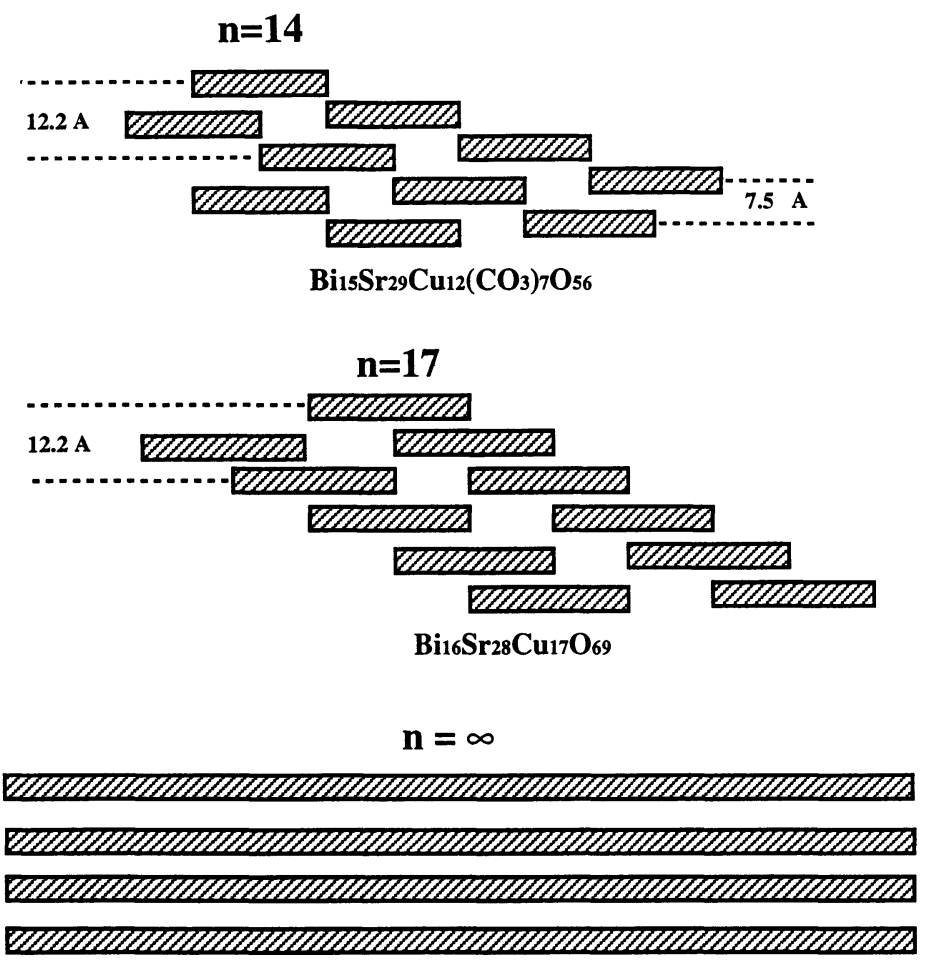

Mother structures : 1201, 2201, 1201/S2 CC and 2201/S2CC

Fig. 21. - Schematical drawing of the copper ribbon width for the different collapsed and uncollapsed cuprate structures.

way, among the oxycarbonates, $\mathrm{Bi}_{15} \mathrm{Sr}_{29} \mathrm{Cu}_{12}\left(\mathrm{CO}_{3}\right)_{7} \mathrm{Q}_{56}$, is the only one that displays triple rock salt type ribbons $\left[(\mathrm{BiO})_{2} \mathrm{SrO}\right]_{\infty}$, the three other oxycarbonates having double rock salt-type ribbons such as $[(\mathrm{TlO})(\mathrm{SrO})]_{\infty}$.

A first important observation is that a shearing mechanism applied to the bismuth cuprates leads systematically to a rupture of the $\left[\mathrm{CuO}_{2}\right]_{\infty}$ layers with a disappearance of superconductivity. This view point is confirmed by electrical resistivity measurements performed on $\mathrm{Bi}_{16} \mathrm{Sr}_{28} \mathrm{Cu}_{17} \mathrm{O}_{69+\delta}$; a semiconducting behaviour of this phase is indeed evidenced whatever the thermal annealing under argon, air or oxygen at low temperature (Tab. III). The situation is different for the oxycarbonates since, in three compounds out of four, the infinite $\left[\mathrm{CuO}_{2}\right]_{\infty}$ layers are maintained 
after shearing due to the fact that the carbonate layers and $[\mathrm{AO}]_{\infty}(\mathrm{A}=\mathrm{Tl}, \mathrm{Hg}, \mathrm{Pb})$ layers are interchangeable; consequently the three phases $\mathrm{TlBa}_{2} \mathrm{Sr}_{2} \mathrm{Cu}_{2}\left(\mathrm{CO}_{3}\right) \mathrm{O}_{7}, \mathrm{HgBa}_{2} \mathrm{Sr}_{2} \mathrm{Cu}_{2}\left(\mathrm{CO}_{3}\right) \mathrm{O}_{6-\delta}$ and $\mathrm{Hg}_{0.5} \mathrm{~Pb}_{0.5} \mathrm{Ba}_{2} \mathrm{Sr}_{2} \mathrm{Cu}_{2}\left(\mathrm{CO}_{3}\right) \mathrm{O}_{7}$ are superconductors, with critical temperatures close to those of the basic structures; in the oxycarbonate $\mathrm{Bi}_{15} \mathrm{Sr}_{29} \mathrm{Cu}_{12}\left(\mathrm{CO}_{3}\right)_{7} \mathrm{O}_{56}$ the bismuth bilayer, much thicker than the carbonate layer, implies an interruption of the $\left[\mathrm{CuO}_{2}\right]_{\infty}$ layers after shearing; consequently, this phase does not superconduct (Tab. III), contrary to the basic structure $\mathrm{Bi}_{2} \mathrm{Sr}_{4} \mathrm{Cu}_{2}$ $\left(\mathrm{CO}_{3}\right) \mathrm{O}_{8}$ that exhibits a $T_{\mathrm{c}}$ of $30 \mathrm{~K}$.

A second important feature concerns the width of the copper ribbons running along [010] of these new collapsed phases. The octahedral or pyramidal copper ribbons and their relative positions are represented in Figure 21 without any drawing of the other cations. It appears that the width of these ribbons which corresponds to $17 \mathrm{CuO}_{5}$ pyramids for the collapsed to 2212 cuprate $(\approx 46 \AA)$ and to 14 octahedra for the collapsed 2201 oxycarbonate $(\approx 35 \AA)$ is significantly larger than those observed for the collapsed 2201-cuprates where the width range from 5 octahedra $(\approx 13.5 \AA)$ to 8 octahedra $(\approx 21.6 \AA)$. In this respect, these new structures are intermediate between the collapsed 2201 cuprates and the collapsed $[1201]_{1}\left[\mathrm{Sr}_{2} \mathrm{CuO}_{2} \mathrm{CO}_{3}\right]_{1}$ and $[2201]_{1}\left[\mathrm{Sr}_{2} \mathrm{CuO}_{2} \mathrm{CO}_{3}\right]_{m}$ oxycarbonates which exhibit infinite copper layers instead of tapes. This interruption of the copper layers has very interesting potential applications for increasing the critical current of the superconducting cuprates, such as creation of pinning centers.

\section{Acknowledgements}

The authors are gratefull to the European Community for financial support.

\section{References}

[1] Raveau B., Michel C., Hervieu M. and Groult D., Crystal Chemistry of High Tc Superconducting Oxides, Springer Series In Materials Science (1991).

[2] Rouillon T., Maignan A., Hervieu M., Michel C. and Raveau B., Physica C 171 (1990) 7.

[3] Liu R.S., Hu S.F., Gameson I., Edwards P.P., Maignan A., Hervieu M., Rouillon T., Groult D. and Raveau B., J. Solid State Chem. 93 (1990) 276.

[4] Liu R.S., Hu S.F., Gameson I., Obertelli S.D., Edwards P.P., Jeffersson D.A., Maignan A., Hervieu M., Rouillon T., Groult D., Provost J. and Raveau B., Physica C 190 (1990) 99.

[5] Maignan A., Rouillon T., Groult D., Provost J., Hervieu M., Michel C., Raveau B., Liu R.S. and Edwards P.P., Physica C 177 (1991) 4.

[6] Liu R.S., Groult D., Maignan A., Hu S.F., Jefferson D.A., Raveau B., Michel C., Hervieu M. and Edwards P.P., Physica C 195 (1992) 35.

[7] Daniel Ph., Maignan A., Groult D., Hervieu M. and Raveau B., Physica C 211 (1993) 209.

[8] Maignan A., Groult D., Liu R.S., Rouillon T., Daniel Ph., Michel C., Hervieu M. and Raveau B., J. Solic State Chem. 102 (1993) 31.

[9] Putilin S.N., Antipov E.V., Chmaissen O. and Marezio M., Nature 362 (1993) 226.

[10] Putilin S.N., Antipov E.V. and Marezio M., Physica C 212 (1993) 266.

[11] Schilling A., Cantoni M., Quo J.D. and Ott M.R., Nature 263 (1993) 56.

[12] Antipov E.V., Loureiro S.M., Chaillout C., Capponi J.J., Bordet P., Tholence J.L., Putilin A.N. and Marezio M., Physica C 215 (1993) 1.

[13] Antipov E.V., Capponi J.J., Chaillout C., Chmaissen O., Loureiro S.M., Marezio M., Putilin S.N., Santoro A. and Tholence J.L., Physica C 218 (1993) 348. 
[14] Pelloquin D., Michel C., Van Tendeloo G., Maignan A., Hervieu M. and Raveau B., Physica C 214 (1993) 87.

[15] Goutenoire F., Daniel Ph., Hervieu M., Van Tendeloo G., Michel C., Maignan A. and Raveau B., Physica C 216 (1993) 243.

[16] Shimoyama J., Hahakura S., Kitazawa K., Yamafuji K. and Kishio K., Physica C 224 (1994) 1.

[17] Singh K.K., Kirtikor V., Sinha A.P.B. and Morris D.E., Physica C 231 (1994) 9.

[18] Hahakura S., Shimoyama J., Shiino O. and Kishio K., Physica C 233 (1994) 1.

[19] Hahakura S., Shimoyama J., Shiino O., Hasegawa T., Kitazawa K. and Kishio K., Proc. of M2s-Htsc Iv (1994-Grenoble), Physica C (1994) 235-240.

[20] Chmaissen O. and Sheng Z.A., Physica C 242 (1995) 23.

[21] Hervieu M., Van Tendeloo G., Maignan A., Michel C., Goutenoire F. and Raveau B., Physica C 216 (1993) 264.

[22] Pelloquin D., Hervieu M., Michel C., Van Tendeloo G., Maignan A. and Raveau B., Physica C 216 (1993) 257.

[23] Martin C., Hervieu M., Huve M., Michel C., Maignan A., Van Tendeloo G. and Raveau B., Physica C 222 (1994) 19.

[24] Maignan A., Hervieu M., Martin C., Michel C. and Raveau B., Physica C 232 (1994) 15-21.

[25] Maignan A., Van Tendeloo G., Hervieu M., Michel C. and Raveau B., Physica C 212 (1993) 239.

[26] Maignan A., Michel C., Van Tendeloo G., Hervieu M. and Raveau B., Physica C 216 (1993) 1.

[27] Michel C., Hervieu M., Maignan A., Pelloquin D., Badri V. and Raveau B., Physica C 241 (1995) 1.

[28] Iqbal Z., Barry J.C., Owens F.J., Rinzler A.G., Yang D. and Reidinger F., Phys. Rev. B. 49 (1994) 12322.

[29] Maignan A., Pelloquin D., Hervieu M., Michel C. and Raveau B., Physica C 243 (1995) 214.

[30] Maignan A., Pelloquin D., Malo S., Michel C., Hervieu M. and Raveau B., Physica C 243 (1995) 233.

[31] Van Tendeloo G., Hervieu M., Zhang Xf. and Raveau B., J. Solid State Chem. 114 (1995) 369.

[32] Martin C., Hervieu M., Van Tendeloo G., Goutenoire F., Michel C., Maignan A. and Raveau B., Solid State Commun. 93 (1995) 53.

[33] Huve M., Martin C., Maignan A., Van Tendeloo G., Hervieu M. and Raveau B., J. Solid State Chem. 114 (1995) 230.

[34] Fomichev D.V., Kharlanov A.L., Antipov E.V. and KovbaL.M., Superconductivity 3 (1990) 126.

[35] Huve M., Michel C., Maignan A., Hervieu M., Martin C. and Raveau B., Physica C 205 (1993) 219.

[36] Maignan A., Huve M., Michel C., Hervieu M., Martin C. and Raveau B., Physica C 208 (1993) 149.

[37] Hervieu M., Michel C., Huve M., Martin C., Maignan A. and Raveau B., Microsc. Microanal. Microstruct. 4 (1993) 41.

[38] Pelloquin D., Hervieu M., Michel C., Maignan A. and Raveau B., Physica C 227 (1994) 215.

[39] Martin C., Hervieu M., Huve M., Michel C., Maignan A., Van Tendeloo G. and Raveau B., Physica C 222 (1994) 19.

[40] Pelloquin D., Hervieu M., Malo S., Michel C., Maignan A. and Raveau B., Physica C 246 (1995) 1.

[41] Maignan A., Pelloquin D., Malo S., Michel C., Hervieu M. and Raveau B., Physica C 249 (1995) 220.

[42] Pelloquin D., Caldes M., Maignan A., Michel C., Hervieu M. and Raveau B., Physica C 208 (1993) 121.

[43] Pelloquin D., Caldes M., Michel C., Maignan A., Hervieu M. and Raveau B., Physica C 217 (1993) 27.

[44] Pelloquin D., Maignan A., Caldes M., Michel C., Hervieu M. and Raveau B., Physica C 212 (1993) 199.

[45] Hervieu M., Caldes M., Michel C.,Pelloquin D. and Raveau B., J. Solid State Chem. 108 (1994) 346.

[46] Pelloquin D., Hervieu M., Maignan A., Caldes M., Michel C. and Raveau B., Physica C 232 (1994) 75.

[47] Hervieu M., Pelloquin D., Michel C., Van Tendeloo G. and Raveau B., J. Solid State Chem. 112 (1994) 139.

[48] Zhang Xf., Van Tendeloo G., Amelinckx S., Pelloquin D., Michel C., M. Hervieu M. and Raveau B., J. Solid State Chem. 113 (1994) 327. 
[49] Allen J.L., Mercey B., Prellier W., Hamet J.F., Hervieu M. and Raveau B., Physica C 241 (1995) 158.

[50] Pelloquin D., Hervieu M., Michel C., Caldes M. and Raveau B., J. Solid State Chem. 116 (1995) 53.

[51] Goutenoire F., Hervieu M., Maignan A., Michel C., Martin C. and Raveau B., Physica C 210 (1993) 359.

[52] Parkin S.S.P., Lee V.Y., Nazzal A.I., Savoy R., Huang T.C., Gorman G. and Beyers R., Phys. Rev. B 38 (1988) 6531.

[53] Kwei Shi J.B. and Ku H.C., Physica C 174 (1991) 180.

[54] Matsui Y., Ogawa M., Muehara, Nakata H. and Akimitsu J., Physica C 217 (1993) 287.

[55] Kikuchi M., Ohshima E., Onhishi N., Muraoka Y., Nakajima S., Aoyagi E., Ogawla M., Akimitsu J., Oku T., Hiraga K. and Sono Y., Physica C 219 (1993) 200.

[56] Uehara M., Sahoda S., Nakata H., Akimitsu J. and Matsui Y., Physica C 222 (1994) 27.

[57] Huve M., Van Tendeloo G., Hervieu M., Maignan A. and Raveau B., Physica C 231 (1994) 15-20.

[58] Huve M., Hervieu M., Van Tendeloo G., Maignan A. and Raveau B., to be published.

[59] Ikeda Y., Ito H., Simomura S., Oue Y., Inaba K., Hiroi Z. and Takano M., Physica C 159 (1989) 93.

[60] Hervieu M., Michel C., Pham A.Q. and Raveau B., J. Solid State Chem. 104 (1993) 289.

[61] Hervieu M., Michel C., Caldes M.T., Pham A.Q. and Raveau B., J. Solid State Chem. 107 (1993) 117.

[62] Hervieu M., Caldes M.T., Pelloquin D., Michel C., Cabrera S. and Raveau B., J. Solid State Chem. 119 (1995) 169-175.

[63] Hervieu M., Caldes M.T., Pelloquin D., Michel C., Cabrera S. and Raveau B., J. Mater. Chem. 6 (1996) 175-181.

[64] Domenges B., Hervieu M. and Raveau B., Physica C 207 (1993) 65.

[65] Domenges B., Boullay P., Hervieu M. and Raveau B., J. Solid State Chem. 108 (1994) 219.

[66] Hervieu M., Michel C. and Raveau B., Chem. Mater. 5 (1993) 1126.

[67] Miyazaki Y., Yamane H. and Hirai T., Physica C 198 (1992) 53.

[68] Maignan A., Hervieu M., Michel C. and Raveau B., Physica C 208 (1993) 116.

[69] Raveau B., Huve M., Maignan A., Hervieu M., Michel C., Domenges B. and Martin C., Physica C 209 (1993) 163.

[70] Michel C., Hervieu M., Borel Mm., Grandin A., Deslandes F., Provost J. and Raveau B., Z. Phys. B 68 (1987) 421.

[71] Akimitsu J., Uehara M., Ogawa M., Omimoto K.T., Miyazaki H., Yamane H., Hirai T., Kinoshita K. and Matsui Y., Physica C 201 (1992) 320.

[72] Kawashima T., Matsui Y. and Takayama-Muromachi E., Physica C 224 (1994) 69.

[73] Alario Franco M.A., Bordet P., Capponi J.J., Chaillout C., Chenavas J., Fournier T., Marezio M., Souletie B., Sulpice A., Tholence J.L., Colliex C., Argoud R., Baldonedo J.L., Gorius M.F. and Perroux M., Physica C 231 (1994) 103. 